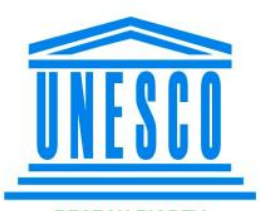

RESEAU BIODEV
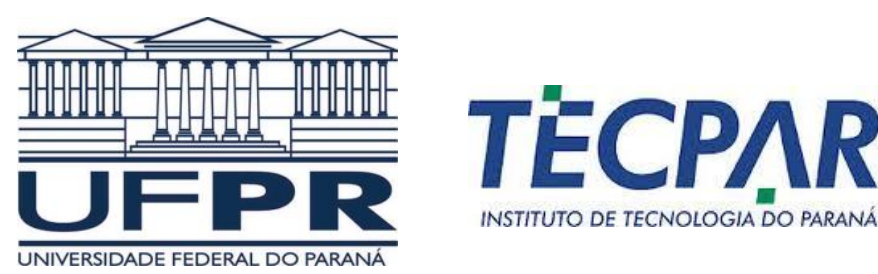

INSTITUTO DE TECNOLOGIA DO PARANA

AIX-MARSEILLE UNIVERSITÉ

Master of Sciences - BIODEV (M2)

Mention Microbiology, Plant Biology and Biotechnologies

FEDERAL UNIVERSITY OF PARANÁ

Department of Bioprocess Engineering and Biotechnology

Programa De Pós-Graduação Em Processos Biotecnológicos

\title{
Development of a rabies vaccine in cell culture for veterinary use in the lyophilized form
}

MATHEUS GONÇALVES SEVERO

Supervisor:

PhD Carlos Ricardo Soccol

Co-supervisor:

Aurelio Santo Zeferino

September, 2013

Curitiba - Paraná - Brazil 


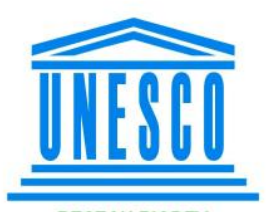

RESEAU BIODEV

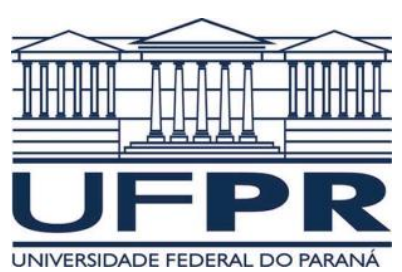

$T E C P \Lambda R$

AIX-MARSEILLE UNIVERSITÉ

Master of Sciences - BIODEV (M2)

Mention Microbiology, Plant Biology and Biotechnologies

FEDERAL UNIVERSITY OF PARANÁ

Department of Bioprocess Engineering and Biotechnology

Programa De Pós-Graduação Em Processos Biotecnológicos

\section{Development of a rabies vaccine in cell culture for veterinary use in the lyophilized form}

MATHEUS GONÇALVES SEVERO

Presented in fulfillment of the requirements for the

Degree Master of Sciences: Mention Microbiology, Plant Biology and Biotechnologies at the Aix-Marseille Université and Federal University of Paraná.

Supervisor:

PhD Carlos Ricardo Soccol

Co-supervisor:

Aurelio Santo Zeferino

September, 2013

Curitiba - Paraná - Brazil 


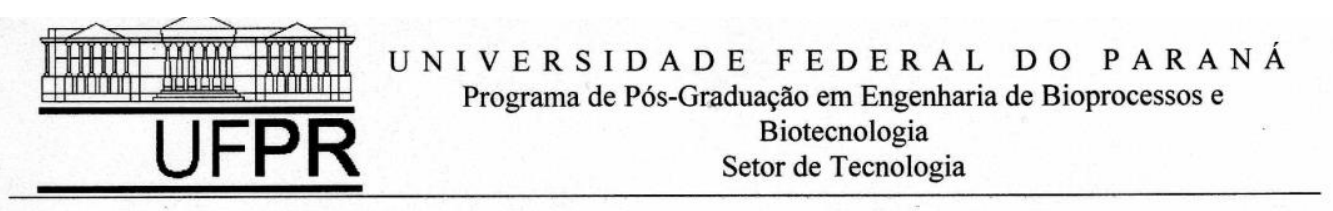

\section{RELATÓRIO DE DEFESA DE DISSERTAÇÃO DE MESTRADO}

Aos três dias do mês de outubro de 2013, na Sala de Aula do PPGEBB, por Videoconferência, no primeiro andar das Usinas Piloto B, no Centro Politécnico da Universidade Federal do Paraná, Jardim das Américas, foi instalada pela Profa ${ }^{2} r^{a}$ Luciana Porto de Souza Vandenberghe, Coordenadora do Curso de Pós-Graduação em Engenharia de Bioprocessos e Biotecnologia, a banca examinadora para a Octogésima Primeira Defesa de Dissertação de Mestrado, área de concentração: Saúde Humana e Animal. Estiveram presentes no Ato, além da Coordenadora do Curso de PósGraduação, professores, alunos e visitantes.

A Banca Examinadora, atendendo determinação do Colegiado do Curso de Pós-Graduação em Engenharia de Bioprocessos e Biotecnologia ficou constituída pelos membros: Prof Dr Craic Faulds (Aix Marselle Université), Prof $\mathrm{Dr}$ Jean-Claude Sigoillot (Aix Marselle Université), Profa Dra Vanete Thomaz Soccol (UFPR), e Prof Dr Carlos Ricardo Soccol (UFPR- orientador da dissertação).

Às $7 \mathrm{~h} 30$, a banca iniciou os trabalhos, convidando o candidato Matheus Gonçalves Severo a fazer a apresentação da dissertação intitulada: "Development of a rabies vaccine in cell culture for veterinary use in the lyophilized form". Encerrada a apresentação, iniciou-se a fase de arguição pelos membros participantes.

Tendo em vista a dissertação e a arguição, a banca composta pelos membros Dr Craic Faulds, Dr Jean-Claude Sigoillot, Dr ${ }^{\mathrm{a}}$ Vanete Thomaz Soccol, e Dr Carlos Ricardo Soccol declarou o candidato $\triangle P R O V A D O$ (de acordo com a determinação dos Artigos 59 a 68 da Resolução 65/09 de 30.10.09).

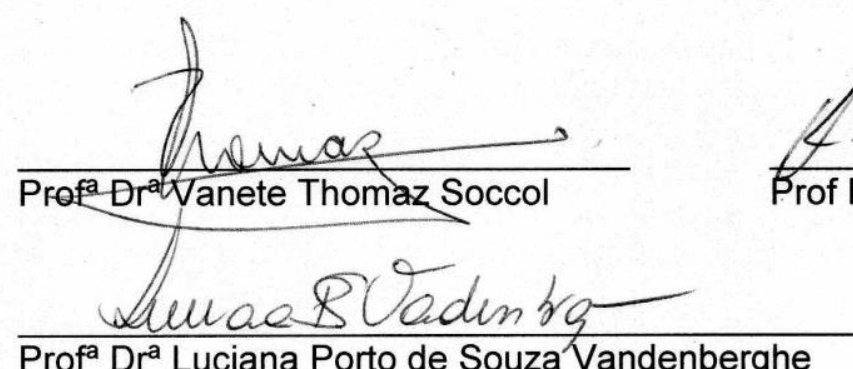

Curitiba; 3 de Outubro de 2013

Prof $^{\mathrm{a}} \mathrm{Dr}^{\mathrm{a}}$ Luciana Porto de Souza Vandenberghe 


\begin{abstract}
Rabies is a viral zoonosis with 61,000 estimated deaths per year. Rabies vaccine is the best treatment pre and post exposure and virus can be produced in animal cells for veterinary use. This work had two objectives. The first one was to test three viral inocula (MOI $0.01, \mathrm{MOI} 0.03$ and $1 \%$ of working volume) in BHK-21 cells cultivated in $1.5 \mathrm{~L}$ spinner, comparing kinects and virus titration to determine the best inoculum. The second one was to freeze dry 12 formulations of excipients with an inactivated viral suspension, comparing visual aspects and residual moisture to select the best formulations. The best inoculum was $1 \%$ of working volume and the best excipients were trehalose, sucrose, dextran and mannitol.
\end{abstract}

Key words: Rabies, Multiplicity of Infection, Freeze Dry. 


\section{Resumo}

Raiva é uma zoonose viral com 61.000 mortes estimadas por ano. A vacina antirrábica é o melhor tratamento pré e pós-exposição e o vírus pode ser produzido em células animais para uso veterinário. Este trabalho teve dois objetivos. $O$ primeiro foi testar três inóculos virais ( $\mathrm{MOI}$ 0,01, $\mathrm{MOI}$ 0,03 e $1 \%$ do volume de trabalho) em células BHK-21 cultivadas em spinner de 1,5 L, comparando resultados de cinética e titulação viral para determinar o melhor inóculo. $O$ segundo foi liofilizar 12 formulações de excipientes com uma suspensão viral inativada, comparando aspectos visuais e umidade residual para selecionar as melhores formulações. O melhor inóculo foi $1 \%$ do volume de trabalho e os melhores excipientes foram trealose, sacarose, dextrana e manitol.

Palavras-chave: Raiva, Multiplicidade de Infecção, Liofilização. 


\section{Acknowledgments}

Firstly I would like to thank God, for giving me daily opportunities of personal and professional growth and for taking care of me in all moments of this work.

I thank PhD Carlos Ricardo Soccol for believing in my capacities, giving me the opportunity of working at TECPAR and studying at an international institution for my master's degree.

PhD Vanete Soccol for her help, suggestions and for her encouragement to believe in myself and finish this dissertation on time.

All the Professors of BIODEV Master of Sciences for the interesting courses and great opportunity of learning.

Aurelio Zeferino for the friendship, trusting, support, dedication and help since I entered at TECPAR and for elaborate my dissertation's theme. Your contribution was indispensable for this work.

Angela Preto and Emerson Batista who taught me all I know about rabies virus and for their support during the project.

For all people at Laboratório de Vacinas Virais Veterinárias and Engenharia Bioindustrial for the daily support and friendship, for helping me in the project experiments even during the weekends.

For all people at Laboratorio de Controle da Qualidade, Laboratório de Química Fina, specially to Alexandre Lôr, Luciana Lopes and Marcelo Ribani for support and help in the experiments.

For all people at Laboratório de Antíngenos Veterinários, specially to Rubens Chaguri for let me use the freeze dryer and other equipments during all the experiments and to Rafael Igreja who taught me how to use a freeze dryer, helped me with ideas discussions, being in my side during all the lyophilization processes. 
All my colleagues from the bench, especially Gilberto Delinski and Thaisa Scheuer for theirs friendship, patience, collaboration and support during the report elaboration.

PhD Neuza Gallina and Francisco Liauw of Butantan Institute who provided me knowledge about lyophilization and help me in the elaboration of lyophilization protocols.

I also thank my sponsors for their partial or total support of this project (Rede Paranaense de Metrologia, TECPAR, UFPR, UNESCO).

But most of all I have to thank my parents Jorge and Susana and my brother Lucas who supported me in all of the moments of this work until the very last end, trying to understand my work to give suggestions and for theirs infinite patience and love. And also to my girlfriend Anna who never gave up on me and provide me with affection, friendship, support and strength during the entire time.

Finally I am thankful to all those who directly or indirectly contributed to the elaboration of this Master's dissertation. 


\section{Presentation of the Institutions where the project was developed}

The present project was developed in two Institutions: Paraná's Institute of Technology (TECPAR) and Parana's Federal University (UFPR) both located in Curitiba, Paraná, Brazil.

TECPAR is a public company founded in 1940 and linked to the Secretariat of Science, Technology and Higher Education of Paraná. TECPAR acts in two main areas: bioproducts and technology solutions. The bioproducts produced are antirabies vaccine for veterinary use, tetan monomeric protein for production of triple vaccine (HIB - Haemophilus influenza type B for human use) and diagnostic test kit for detection of Leucosis, Tuberculosis and Brucellosis in cattle. The technology solutions include projects in energy, strategic studies and intelligent systems engineering for other companies.

TECPAR produces the anti-rabies vaccine since 1944. The first method of production utilized bovine and equine brains as substrate. The method of production suffered several changes and nowadays the vaccine is made using cell culture as substrate. The Institute supplies the Ministry of Health with the antirabies vaccine which is distributed for canines and felines in a national rabies vaccination campaign. TECPAR also does research and development to optimize the process and provide new forms of presentation of rabies vaccine, like the lyophilized form.

UFPR was created in December 19, 1912 and is regarded as the oldest Brazilian University. According to Webometrics Ranking of World Universities, UFPR ranks $10^{\text {th }}$ in the Universities of Brazil and $15^{\text {th }}$ in the Universities across the Latin America.

The University nowadays has facilities across the capital Curitiba and other cities of the State of Paraná. It offers 88 options of graduation courses, 52 master degrees and 35 doctoral programs.

Between the graduation courses, the Bioprocess Engineering and Biotechnology is highlighted as one of the best courses, forming professionals capable of acting in several areas of knowledge such as industrial, environmental, health, agricultural, foods and beverages to list a few. The course was created in UFPR in the year 2000 by PhD Carlos Ricardo Soccol. 


\section{Summary}

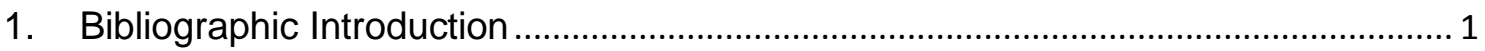

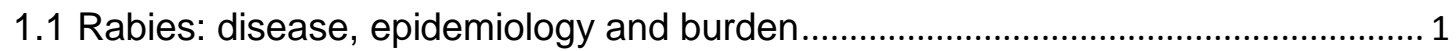

1.2 Rabies: classification, proteins and cell infection..................................................... 1

1.3 Rabies vaccines: definition, generations and first rabies vaccine ............................ 2

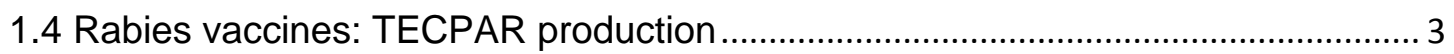

1.5 Lyophilization: process, use for immunobiologicals and cryoprotectors most used

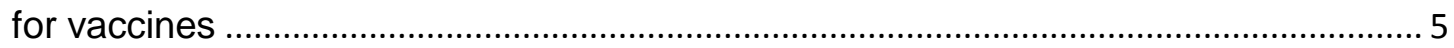

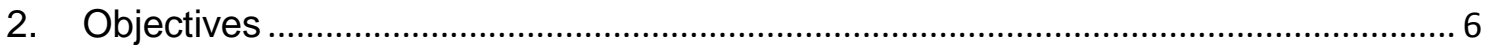

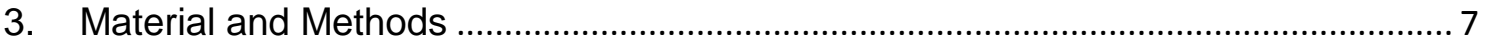

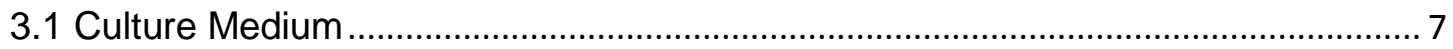

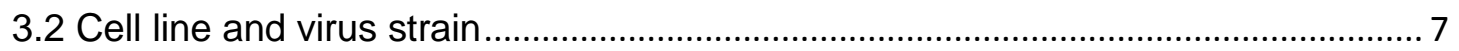

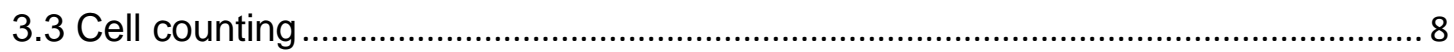

3.4 BHK-21 cell production for infection in spinner for development experiments....... 8

3.5 Cell culture infection in spinner for development experiments .................................. 8

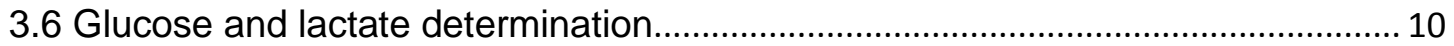

3.7 Infection rate by direct immunofluorescence ............................................................... 10

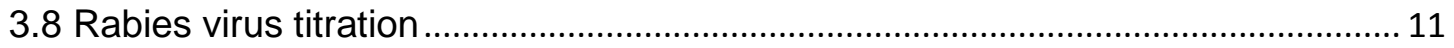

3.9 Preparation of a vaccine for the lyophilization experiments ..................................... 12

3.10 Selection of excipients for lyophilization ............................................................... 12

3.11 Preparation of excipient solutions and vaccine formulation ................................ 14

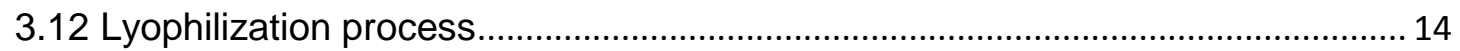

3.13 Visual aspects evaluation of lyophilized vials........................................................ 15

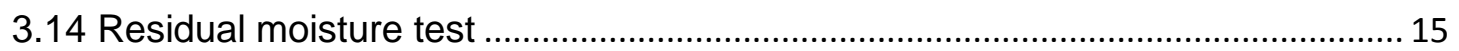

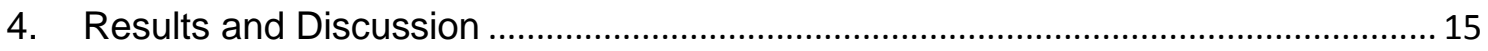

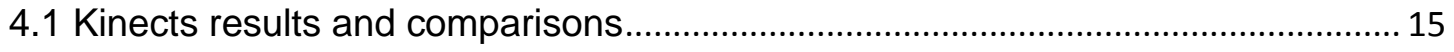

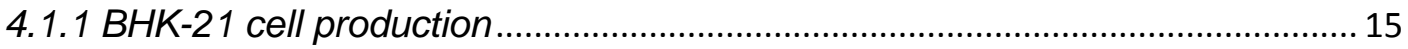

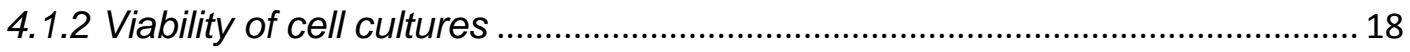

4.1.3 Metabolites consumption and production ........................................................ 19

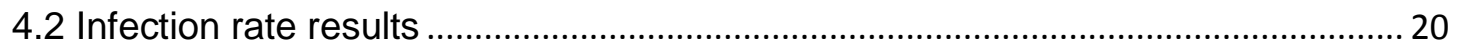

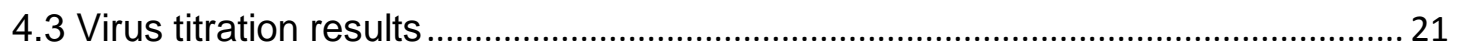

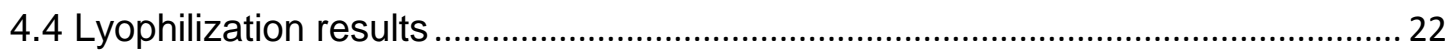

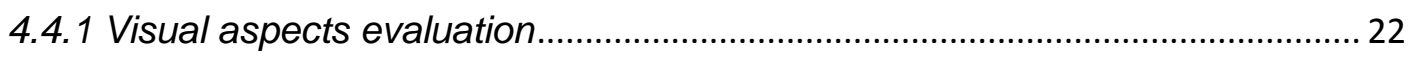

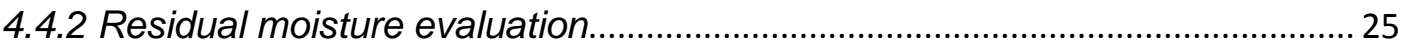




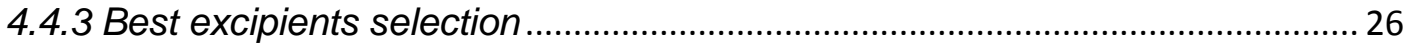

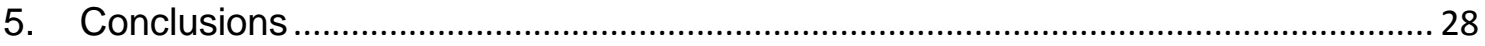

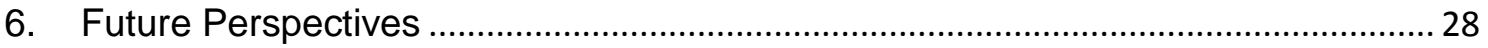

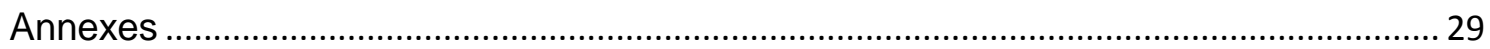

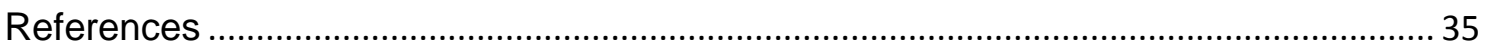




\section{List of Figures}

Figure 1.1: Rabies wide world distribution and risk exposition. ..........................28

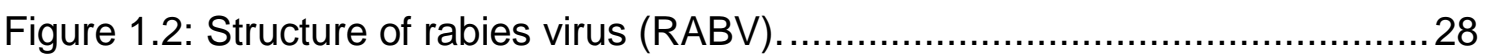

Figure 1.3: Cycle of viral infection and replication of RABV inside one neuron. .....29

Figure 3.1: Formula for calculating the correct volume for infection of spinners.......8

Figure 3.2: Formula for calculating specific growth rate for cell cultures............... 10

Figure 3.3: Direct immunofluorescence assay ready for reading. ..........................30

Figure 3.4: Example of one microplate filled with samples...................................31

Figure 3.5: $7.5 \mathrm{~mL}$ glass vial filled with $1 \mathrm{~mL}$ and partially closed with a rubber

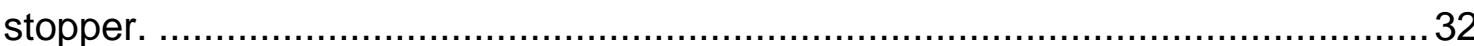

Figure 4.1: Cell growth curves obtained for the four spinners cultivation in

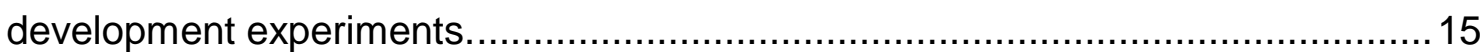

Figure 4.2: Examples of classes in a direct immunofluorescence assay................32

Figure 4.3: Virus titration curves for the three infected spinners. .........................20

Figure 4.4: Examples of positive and negative fields in the rabies virus titration....33

Figure 4.5: Lyophilized cakes part one. ....................................................... 22

Figure 4.6: Lyophilized cakes part two......................................................... 22 


\section{List of Tables}

Table 3.1: Classes and requirements for evaluate direct immunofluorescence .11

Table 3.2: Scheme of samples and dilutions for virus titration in 96 wells microplate. . 31

Table 3.3: NT ( $\mathrm{NaCl}$ - Tris) Buffer for buffer exchange of IVS.................................. 32

Table 3.4: Type and cost of the selected excipients ............................................ 13

Table 3.5: Excipients selected and theirs stock solution concentration ....................... 14

Table 3.6: Description of the best lyophilization protocol ....................................... 14

Table 4.1: Maximum specific growth rate for the four spinners............................... 18

Table 4.2: Rate of cell culture viabilities for the four spinners.................................. 18

Table 4.3: Minimum glucose concentration and maximum lactate production for the

culture cells in four spinners during the 10 days of infection................................... 19

Table 4.4: Infection rates of virus inside cells................................................... 20

Table 4.5: Visual aspects evaluation of lyophilized cakes. ...................................... 24

Table 4.6: Time and $\mathrm{pH}$ evaluation of reconstituted cakes. ...................................... 24

Table 4.7: Residual moisture results for lyophilized cakes. ....................................25 


\section{Bibliographic Introduction}

1.1 Rabies: disease, epidemiology and burden

Rabies is a viral zoonosis that occurs in more than 100 countries and territories (Figure 1.1 in Annexes). There were 61,000 estimated cases of death from rabies in the world in the year 2010 according to the informal group Partners for Rabies Prevention (WHO, 2013). The estimated annual cost of rabies is US\$ 6 billion, covering pre and post exposure treatments and loss of productivity due to premature deaths of workers (WHO, 2013).

The infection usually occurs when an infected animal causes a transdermal bite or scratch in the victim. Transmission may also occur when infectious material, usually saliva, comes into direct contact with the victim's mucosa or with fresh skin wounds. The incubation period is typically 1 to 3 months, but may vary from less than a week to more than a year (WHO, 2010).

Inoculated virus is transported to the central nervous system (CNS). On arrival in the brain, it replicates and disseminates rapidly in many different tissues including the salivary glands (WHO, 2010). The acute disease includes pain or paraesthesia close to the bite site and is often associated with fever, fatigue and weakness in associated limbs. Non-specific neurological symptoms including headache and anxiety are often experienced before the development of encephalitis and it is usually only at this point those patients seek medical help and admission to hospital (Johnson et al., 2010).

As the virus spreads through the CNS, progressive fatal encephalomyelitis develops, characterized by hyperactivity and fluctuating consciousness and, in cases of furious rabies, hydrophobia or aerophobia, or both. Death occurs by cardiorespiratory arrest within a few days (WHO, 2010).

\subsection{Rabies: classification, proteins and cell infection}

The rabies virus (RABV) belongs to order Mononegavirales and family Rhabdoviridae. This family has three genera: Vesiculovirus (which prototype is the vesicular stomatitis virus), Ephemerovirus (which prototype is the bovine ephemeral fever virus) and Lyssavirus (which prototype is the Rabies Virus) (Murphy et al., 1995). RABV and variants known as "rabies related" virus belongs to one of the 
fourteen Lyssavirus genotypes, all of them capable to produce a rabies-like encephalomyelitis (WHO, 2013).

The Lyssavirus stable infective particles (virions) have bullet-shaped form with average length of $180 \mathrm{~nm}$ and average diameter of $75 \mathrm{~nm}$ (Davies et al., 1963). Lyssaviruses, like other Rhabdoviruses, consist mainly of RNA (2-3\%), protein (67-74\%), lipid (20-26\%) and carbohydrate (3\%) as integral components (percent of total mass) of their structure (Wunner, 1991).

The RABV genome is a non-segmented single-stranded RNA, which has a negative-sense polarity. This implies that the minus-strand genome RNA, when free of protein, is not infectious for the victim's cells (Wunner, 2007). The genome analysis reveals the presence of five proteins: a nucleoprotein $(N)$, a phosphoprotein $(\mathrm{P})$, a matrix protein $(\mathrm{M})$ a RNA polymerase RNA-dependent $(\mathrm{L})$ a glycoprotein (G), which carries the main antigenic sites (Batista et al., 2007; WHO, 2010). RABV structure is showed in Figure 1.2 in Annexes.

The cycle of infection and replication of RABV can be summarized in the following stages: (1) adsorption of virions to host cell, (2) penetration of the virion into the cell, (3) removal of protein-RNA complex proteins; (4) transcription of viral RNA, (5) translation of mRNAs, (6) processing of proteins, (7) viral RNA replication, (8) assembly of virions, and (9) budding (Nadin-Davis, 2010). A scheme of infection of a neuron cell is showed in Figure 1.3 in Annexes.

In the virion morphogenesis, the proteins $\mathrm{N}, \mathrm{P}$ and $\mathrm{L}$ newly synthesized in the cytoplasm adhere to nascent viral RNA to form the nucleocapsid. The nucleocapsid is then stabilized by the M protein, which is responsible for giving the nucleocapsid its bullet-shaped morphology. The protein G, which requires glycosylation, is processed in rough endoplasmic reticulum and then goes to the host cell membrane. Finally, the nucleocapsid-protein $M$ interact with cytoplasmic membrane fragments which contain protein $G$ to finish virions assembling and proceeds to budding of these new virion to further spread of the virus (HIROSE \& MONTAÑO-Villegas 1996; Wunner, 2007)

\subsection{Rabies vaccines: definition, generations and first rabies vaccine}

A vaccine is any preparation intended to produce immunity to a disease by stimulating the production of antibodies (WHO, 2013). The most common method of administering vaccines is by injection. But some vaccines are given by mouth or 
nasal spray (WHO, 2013). The first rabies vaccine was developed by Louis Pasteur and Emile Roux in 1885 (cited by Bunn, 1991).

Talking specifically about rabies, there were three generations of vaccine production: the first generation utilizes brains of rabbits, sheep, cows, horses and other animals as substrate for virus cultivation. In 1955, Fuenzalida and Palacios described a vaccine using suckling mouse brain as substrate (Fuenzalida \& Palacios, 1955) and Peck and collaborators described a vaccine using duck embryonated eggs as substrate (Peck et al, 1955). The second generation uses cell cultures for producing rabies vaccine. In 1960, Fenje announced the first vaccine to be produced on hamster kidney tissue (Fenje, 1960). In the next years there were a great amount of reunions and congresses for debating of researches all over the world and standardization of the work which enabled the development and then the rapid commercialization of vaccines for veterinary use. This development benefitted from four favorable factors: (1) the cell lines, such as BHK (Baby Hamster Kidney), were accepted for the production of vaccines for use in animals; (2) viral multiplication is excellent in these cells; (3) these systems permitted an industrial scaling up of the cultures; (4) the addition of adjuvant was authorized to these veterinary vaccines (Roumiantzeff et al., 1985). The third generation of rabies vaccines is already available: the vaccinia-rabies glycoprotein recombinant vaccine is presently applied on a large scale in some European countries for immunization of wildlife. The canarypox recombinant vaccine has already been considered and successfully tested for human immunization (Sureau, 1992).

Talking about vaccine production itself, after cell growing and virus production it is necessary to inactivate the virus. Beta-propiolactone (BPL), ultraviolet (UV) light and acetylethyleneimine are used as inactivating agents, and BPL is the most utilized (Reculard, 1996). Once inactivated, adjuvants are added to increase the immune response to the antigen. The most used are aluminum hydroxide, aluminum phosphate, saponin and less commonly used are oil adjuvants (Precausta et al., 1991, Briggs et al., 2002).

\subsection{Rabies vaccines: TECPAR production}

TECPAR used Fuenzalida-Palacios method to produce rabies vaccine for veterinary use over forty years before change it for cell culture vaccine. Since 2010, the Brazilian regulatory agency (MAPA) that control the production of rabies 
vaccine established mandatory the utilization of a different substrate other than mouse brain. To fit the new specifications, TECPAR started to use BHK-21 cells growing in suspension on a stirred bioreactor to produce rabies vaccine. In addition, the bioreactors were equipped with a perfusion system (Aurelio Zeferino, personal communication, 2012).

Animal cells grow substantially slower than most microorganisms, and lacking a protective cell wall, they are also more fragile. Therefore, one is limited to very gentle culture conditions and relatively low cell concentrations. One way to increase the cell concentration, yet maintain gentle culture conditions is the perfusion method (Furey, 2000).

A perfusion culture is one in which waste medium is continuously removed from the culture and the displaced medium is replenished with fresh medium. The constant addition of fresh medium and elimination of waste products provides the cells with the environment they require to achieve high cell concentrations and with that higher productivity (Furey, 2000).

In the context of virus multiplication in cells, the concept of Multiplicity of infection (MOI) must be explained. $\mathrm{MOI}$ is a frequently used term in virology which refers to the number of virions that are added per cell during infection. If one million virions are added to one million cells, the $\mathrm{MOI}$ is one. If ten million virions are added, the MOI is ten. Add 100,000 virions, and the MOI is 0.1 (Racaniello, 2011).

High $\mathrm{MOI}$ is used when the experiment requires that every cell in the culture is infected. By contrast, low $\mathrm{MOI}$ is used when multiple cycles of infection are required. However, it is necessary to determinate the virus titer in order to calculate the MOI (Racaniello, 2011).

Perrin and collaborators (1995) tried to develop a rabies vaccine using BHK21 cell suspension culture in bioreactor with perfusion in 1995 with satisfactory results. They utilized different $\mathrm{MOI}$ for each stage of the adaptation of the cells from monolayer to suspension: $0.003 ; 0.01 ; 0.1$ and 0.3 cells $^{-1}$.

Kallel and collaborators (2002) tested various serum and protein free media for production of rabies vaccines. In spinners, the MOI selected was $0.1 \mathrm{cells}^{-1}$. In bioreactors the $\mathrm{MOI}$ was 0.1 or 0.3 . Works with the same MOls were conducted in Vero cells by Trabelsi and collaborators $(2005,2006)$. Guidolin and collaborators (1983) also tested two different $\mathrm{MOI}\left(0.07\right.$ and $\left.0.046 \mathrm{cells}^{-1}\right)$ for producing rabies vaccines in BHK cells, obtaining satisfactory potency results. 
1.5 Lyophilization: process, use for immunobiologicals and cryoprotectors most used for vaccines

Lyophilization, or freeze drying, is defined as a stabilizing process in which the substance is first frozen and the quantity of the solvent is reduced by sublimation (primary drying). After, a secondary drying (desorption) the reduction achieve values that will no longer support biological growth or chemical reactions. The lyophilization process is composed by five phases: (1) formulation, (2) freezing, (3) primary drying, submitted to vacuum, (4) secondary drying and (5) closure of recipients (Jennings, 2008).

Freeze drying is an established process to improve the stability of labile drugs, especially proteins and complex vehicles like virus vaccines, viral vectors, liposomes and lipid-DNA complexes. However, during freezing and subsequent drying, the drug is exposed to diverse stress factors which can cause significant loss of activity. During freezing, drug stability can be influenced by exposure to icewater interfaces, salt and drug concentration effects, $\mathrm{pH}$ shifts due to selective crystallization of buffer species, and mechanical damage by growing ice crystals. During drying, removal of stabilizing hydration shells can influence the stability of the drug, just to mention the most common known degradation causes (Wang 2000; Lang \& Winter, 2009).

Then, to ensure the drug stability in step drying freeze and subsequent storage, stabilizing excipients have to be employed. Cryoprotectants such as salts, polyols, and sugars are used to stabilize the solution therapeutic in freeze thawing process. Lyoprotectants, especially the disaccharides sucrose and trehalose, can be used to stabilize the drug during drying. Additionally, bulking agents as like mannitol can be added to enable faster drying times and to maintain lyophilisates with an attractive appearance (Wang 2000; Lang \& Winter, 2009). Hubálek in 2003 described a list of different cryoprotectors used in microorganism's conservation. These include: sulfoxides; alcohols and derivatives; saccharides and polysaccharides; amides and imides; heterocyclic compounds; amino acids, proteins, peptides and polypeptides; complex compounds; and surfactants.

It's not necessary to freeze dry the rabies vaccine for veterinary use according to Brazilian regulatory agency (MAPA). Although, the lyophilization does not exclude the cold chain $\left(2\right.$ to $\left.8^{\circ} \mathrm{C}\right)$, the vaccine in the lyophilized form is more stable, has more resistance to temperature shocks and has more shelf time. 


\section{Objectives}

This work has two main objectives: 1- study different multiplicities of infection in order to determine the best inoculum for infection of cell cultures in spinner; 2- select the best excipients in order to freeze dry the rabies vaccine for posterior in vivo tests.

To achieve that, the specific objectives are:

1) Determine the cellular growing kinects before and after virus infection;

2) Determine the viral production with different virus inoculum conditions;

3) Determine the influence of these inoculum seeking greater productivity and higher quantity of harvests above cut off (established by TECPAR);

4) Evaluate the visual aspects and residual moisture of different Iyophilization conditions;

5) Determine the best lyophilization conditions for posterior biological tests. 


\section{Material and Methods}

\subsection{Culture Medium}

The medium used for growing BHK-21 cells before infection was nominated SCM (Standard Culture Medium). It was composed by a combination of DMEM (Dulbecco's Modified Eagle Medium) and Ham's F12 Nutrient Mixture Medium customized for TECPAR use, supplemented with $3 \%$ of fetal bovine serum (FBS) and with $\mathrm{pH}$ adjusted for 7.8 .

After the cell infection with virus particles the medium used was nominated SCMI (Standard Culture Medium for Infection). It was composed by DMEM and Ham's F12 medium but supplemented with $1 \%$ of FBS and with $\mathrm{pH}$ adjusted for 7.8 .

The BHK cells of seed bank and work bank were frozen in liquid nitrogen using a medium nominated FM (Freezing Medium). It was composed by 95\% FBS and $5 \%$ dimethyl sulfoxide (DMSO).

\subsection{Cell line and virus strain}

The cell line used was BHK-21 C13 LVI and it came from Pan American Centre for Foot-and-Mouth Disease (Panaftosa) with 84 passages. The cells were adapted in SCM and a seed bank was made using 30 million cells $/ \mathrm{mL}$ in FM aliquoted in cryotubes and stored at $-196^{\circ} \mathrm{C}$ in liquid nitrogen with 105 passages.

From the seed bank it was prepared a work bank which was used for the experiments of cultivation of cells in spinner flask. At the experiments, the cell line had 118 passages.

The rabies virus strain was Pasteur Virus (PV) adapted for the infection of BHK-21 C13 cells and has one passage. The strain came from Minas Gerais' Federal University (UFMG) and was storage at $-80^{\circ} \mathrm{C}$ ultra freezer. From the original virus was created a seed bank and a work bank, both prepared in BHK cells cultivated with SCM and supplemented with $5 \%(\mathrm{w} / \mathrm{v})$ sucrose before freezing. In the experiments virus from the work bank was directly used for infection of the spinners. 


\subsection{Cell counting}

The cells were counted in hemocytometer. The readings were performed in optical microscope Olympus with 100 times magnification. The cells were stained with $0.5 \%(\mathrm{w} / \mathrm{v})$ Trypan blue in a dilution in which at least 20 cells could be counted per quadrant (Phillips, 1973). The cells were also visually evaluated in terms of morphology, light refringence and size.

3.4 BHK-21 cell production for infection in spinner for development experiments

A cryotube with BHK-21 cells from the work bank was thawed at $37^{\circ} \mathrm{C}$ and used as cell inoculum in a $500 \mathrm{~mL}$ spinner (named $1 \mathrm{~A}$ ) with $80 \mathrm{~mL}$ of SCM. The spinner was incubated at $37^{\circ} \mathrm{C}$ at $55 \mathrm{rpm}$ agitation and cell counting was made every day. When it achieved at least 800,000 cells $/ \mathrm{mL}$, more medium was added to dilute the cells to 200,000 cells/mL and the spinner was incubated again. This proceeded until the spinner has $500 \mathrm{~mL}$ of SCM.

After that $250 \mathrm{~mL}$ of first spinner was transferred to a $1.5 \mathrm{~L}$ spinner. SCM was added to this second spinner to complete $1.25 \mathrm{~L}$ leaving it with 200,000 cells $/ \mathrm{mL}$ again and this second spinner was incubated at $37^{\circ} \mathrm{C}$ at $55 \mathrm{rpm}$. When the concentration reached 1 million cells $/ \mathrm{mL}$, the sample was divided in four spinners (1.1A, 1.2A, 1.3A and 1.4A) each one was completed to $1.5 \mathrm{~L}$ with SCM. The four spinners were incubated with the same conditions. When the concentration of the four spinners reached at least 1 million cells $/ \mathrm{mL}$ each, three of the spinners were infected with the virus strain.

\subsection{Cell culture infection in spinner for development experiments}

The virus titer for the experiment was $10^{6.18}$ Fluorescent Focus-Forming Dose (FFD) per $\mathrm{mL}$, titrated in microplate. The $\mathrm{MOI}$ calculations were made using the following formula:

$$
\text { Vol }_{\text {inoculum }}=\frac{M O I \times C e l_{T o t}}{A n t i \log _{10} \text { Tit }}
$$

Figure 3.1: Formula for calculating the correct volume for infection of spinners. 
Where:

- Volinoculum = volume of inoculum required for the infection, in $\mathrm{mL}$;

- $\mathrm{MOI}=$ multiplicity of infection selected, in FFD/cell;

- $\mathrm{Cel}_{\text {tot }}=$ total number of cells, multiplying the cell concentration for the volume of the flask, in cell;

- Antilog Tit = the anti-logarithm of virus titer, in FFD/mL;

In the development stage assay there were selected three different $\mathrm{MOI}$ for infection. The virus used for all the infected spinners was at the same concentration, therefore the only difference was the volume inoculated in each spinner. The inoculum used corresponding to $1 \%$ of total flask volume (as example $15 \mathrm{~mL}$ in $1.5 \mathrm{~L}$ spinner) is the positive control, used normally for rabies vaccine production on bioreactor. Using the formula it can be calculated that positive control has MOI $0.015 \mathrm{FFD} /$ cell. The experiments also used MOI 0.01 and $0.03 \mathrm{FFD} /$ cell.

When 1 million cells $/ \mathrm{mL}$ was reached in the spinners, the infection protocol was started. In zero day of infection, the $\mathrm{pH}$ was adjusted for 7.4 with sodium bicarbonate $7.5 \%(\mathrm{w} / \mathrm{v})$ and the spinner was placed in a cold room $\left(2\right.$ to $\left.8^{\circ} \mathrm{C}\right)$ for 2 hours to sediment the cells. The supernatant was carefully removed from the spinner, leaving a final volume of $300 \mathrm{~mL}$. Then diethylaminoethanol-dextran (DEAE) $0.5 \%(\mathrm{w} / \mathrm{v})$ was added at $1 \%$ of the remaining volume to optimize the adsorption of the viral particles in the cells. The spinner was incubated at $33^{\circ} \mathrm{C}$ in intermittent agitation: 20 minutes stopped and 5 minutes with 30-35 rpm agitation for 90 minutes.

The four spinners were nominated: Spinner 1.1A became positive control and received $15 \mathrm{~mL}$ of virus; Spinner 1.2A became negative control and it wasn't inoculated with virus; Spinner 1.3A became MOI 0.01 and received $10 \mathrm{~mL}$ of virus; Spinner 1.4A became MOI 0.03 and received $30 \mathrm{~mL}$ of virus.

After inoculation the volume was completed to $1.5 \mathrm{~L}$ with SCMI and incubated at $33^{\circ} \mathrm{C}$ at $55 \mathrm{rpm}$. The assay lasted 10 days after infection. The next days were called days post infection (dpi). In each day, samples were taken for cell counting, infection rate, $\mathrm{pH}$ evaluation, glucose and lactate determination and two samples were frozen for subsequent virus titration. The $\mathrm{pH}$ was adjusted to 7.4 with sodium bicarbonate $7.5 \%$ and the spinner was placed in cold room for cell sedimentation for 2 hours. The maximum volume of medium was discarded, without losing cells, and new SCMI was added in order to achieve $1.5 \mathrm{~L}$ again and the spinner was incubated in $33^{\circ} \mathrm{C}$ at $55 \mathrm{rpm}$. From $3 \mathrm{dpi}$ to $8 \mathrm{dpi}$, the medium was 
harvest instead of discarded, placed in $2 \mathrm{~L}$ roller bottles, identified and stored at $80^{\circ} \mathrm{C}$.

After counting the viable and total cells it was possible to calculate the viability in percentage. Also, the specific growth rate $(\mu)$ can be calculated with an formula adapted for using cell concentration values obtained at the assay (Figure 3.2). The specific growth rate measures the rate of cell multiplication and it is calculated every day post infection.

$$
\mu=\frac{\ln \left(X_{n}\right)-\ln \left(X_{n-1}\right)}{\left(t_{n}-t_{n-1}\right)}
$$

Figure 3.2: Formula for calculating specific growth rate of cell cultures.

Where:

- $\quad \mu=$ specific growth rate, in hours ${ }^{-1}$;

- $\quad X=$ cell concentration, in cells $/ \mathrm{mL}$;

- $\mathrm{t}=$ time, in hours;

- $\quad n$ and n-1 means two succeeded sampling points.

\subsection{Glucose and lactate determination}

Every day a sample of each spinner was taken in microtube and centrifuged at 800 rpm for 5 minutes. Then the supernatant was injected in an YSI 2700 Select Dual-Channel Biochemistry Analyzer (Yellow Springs Instruments, Yellow Springs, Ohio, USA) for determination of residual glucose and lactate production concentration.

\subsection{Infection rate by direct immunofluorescence}

The direct immunofluorescence test was adapted from Batista and collaborators, 2009.

The test was carried out with $50 \mu \mathrm{L}$ of the three infected cultures in separated spaces of a lamina. The lamina was placed on a flat table for 20 min to sediment the cells and dried at room temperature. The next step was fixating the cells using $50 \mu \mathrm{L}$ of acetone $80 \%(\mathrm{v} / \mathrm{v})$ in purified water. The lamina was conserved 
in freezer $\left(-20^{\circ} \mathrm{C}\right)$ for 7 minutes. Then, the acetone was thawed and the lamina was dried at room temperature.

Afterwards it was prepared a solution with anti-rabies nucleocapsid conjugate (Bio-rad code 357-2114) and Evans blue dye (dissolved at 1:40000 in purified water) at 1:20 proportion and $40 \mu \mathrm{L}$ was added to three samples. The lamina was incubated at $37^{\circ} \mathrm{C}$ for $30 \mathrm{~min}$ and then washed three times with $50 \mu \mathrm{L}$ of PBS.

Finally a glass slide was put over the lamina (Figure 3.3) and it was observed in an immunofluorescence microscope Olympus with 100 times magnificence.

The samples were evaluated in terms of fluorescent focus inside the cells. The results were classified like described in Table 3.1

Table 3.1: Classes and requirements for evaluate direct immunofluorescence.

\begin{tabular}{|c|l|}
\hline Class & \multicolumn{1}{c|}{ Requirements } \\
\hline $\mathbf{0}$ & total absence of fluorescent focuses \\
\hline $\mathbf{1}$ & from rare fluorescent focuses to $25 \%$ fluorescent focuses \\
\hline $\mathbf{2}$ & from $25 \%$ to $50 \%$ fluorescent focuses \\
\hline $\mathbf{3}$ & from $50 \%$ to $75 \%$ fluorescent focuses \\
\hline $\mathbf{4}$ & more than $75 \%$ fluorescent focuses \\
\hline
\end{tabular}

\subsection{Rabies virus titration}

The rabies virus titration of samples was made following the Fuches, 2010, protocol previously validated by Moura and colleagues, 2008.

From each infected spinner (in each dpi) a sample was taken totalizing 10 samples per spinner, and centrifuged at $800 \mathrm{rpm}$ for 5 minutes. The supernatant was collected and stored at $-80^{\circ} \mathrm{C}$. These samples were thawed at room temperature at the time of experiment. A reference rabies virus with known titration was used, in duplicate and 2 wells were used for cell control, without infection.

Three microplates with 96 wells were made, each one with the 10 samples (one for each dpi) of one infection. The disposal of the samples and the dilutions used in the titration are described in Annexes (Table 3.2 and Figure 3.4). 


\subsection{Preparation of a vaccine for the lyophilization experiments}

For the lyophilization experiments, an inactivated viral suspension (IVS) 10 times concentrated previously prepared in 75 L NBS bioreactor was used. This IVS was selected in order to test different lyophilization protocols before using the harvests obtained in the development stage and evaluate the performance of the excipients selected.

The harvests from the bioreactor usually have a few cellular debris and another undesirable metabolites. When the IVS is concentrated, these debris are concentrated too. Then it was necessary to clarify this IVS, washing it with buffer solution. The buffer selected was NT (Table 3.3 in Annexes). Before the buffer exchange, it was necessary to concentrate the IVS in order to improve the wash results and to use a minor amount of buffer solution.

The buffer exchange step was performed in a Pellicon tangential filtration system with $100 \mathrm{kDa}$ of porosity (Merck-Millipore, Billerica, Massachusetts, USA). The Pellicon membrane was coupled with a peristaltic pump set up for 55rpm speed. Firstly, the IVS were concentrated from 2 liters to $400 \mathrm{~mL}$, discarding the permeate. Secondly, buffer were continued added to the IVS to wash, totalizing a 5 times volume, also discarding the permeate. Finally, the volume was reestablished with the same buffer and thimerosal $10 \%$ was added at $1: 10,000$ proportion to preserve the IVS. The IVS were stored at cold room.

\subsection{Selection of excipients for lyophilization}

For the lyophilization experiments, 11 excipients were selected:

- 3 disaccharides: sucrose, trehalose and lactose;

- 2 polyalcohols: sorbitol and mannitol;

- 3 amino acids: L-proline, L-serine and L-glutamic acid,

- 3 polymers: dextran 40 (a polysaccharide with molecular weight $40 \mathrm{kDa}$ ), polyethylene glycol (PEG) 3350 (a polyether with average molecular weight 3350 $\mathrm{Da}$ ) and gelatin.

A summary of the selected excipients, theirs respective classes and their estimated prices in dollars is described in Table 3.4. The most expensive excipient is the polymer dextran 40 (4,522 dollars per kilogram) and the cheapest excipient is the polyalcohol sorbitol (55 dollars per kilogram). 
Table 3.4: Type and cost of the selected excipients.

\begin{tabular}{|c|c|c|}
\hline Excipients & Type & Estimated Cost \\
\hline Sucrose & Sugar & US\$ 86/kg \\
\hline Trehalose & Sugar & US\$ 4,211/kg \\
\hline Lactose & Sugar & US\$ 193/kg \\
\hline Sorbitol & Polyalcohol & US\$ 55/kg \\
\hline Mannitol & Polyalcohol & US\$ 232/kg \\
\hline Proline & Amino acid & US\$ 1,263kg \\
\hline Serine & Amino acid & US\$ 1,280/kg \\
\hline Glutamic Acid & Amino acid & US\$ 162/kg \\
\hline Dextran 40 & Polymer & US\$ 4,522/kg \\
\hline PEG 3350 & Polymer & US\$ 254/kg \\
\hline Gelatin & Polymer & US\$ 142/kg \\
\hline
\end{tabular}

The excipients were diluted in purified water (Milli-Q) for the lyophilization experiments and prepared 2 times concentrated in order to prepare stock solutions of each excipient which were used during all the experiments (Table 3.5)

Table 3.5: Excipients selected and theirs stock solution concentration.

\begin{tabular}{|c|c|}
\hline Excipients & Stock Solution $2 x$ concentrated $(w / v)$ \\
\hline Sucrose & $10 \%$ \\
\hline Trehalose & $10 \%$ \\
\hline Lactose & $10 \%$ \\
\hline Sorbitol & $10 \%$ \\
\hline Mannitol & $10 \%$ \\
\hline Proline & $2 \%$ \\
\hline Serine & $2 \%$ \\
\hline Glutamic Acid & $2 \%$ \\
\hline Dextran 40 & $2 \%$ \\
\hline PEG 3350 & $2 \%$ \\
\hline Gelatin & $2 \%$ \\
\hline
\end{tabular}




\subsection{Preparation of excipient solutions and vaccine formulation}

Each vaccine is IVS with a different excipient solution. The vaccine formulation was done mixing together the IVS and the excipients at 1:1 proportion, homogenizing it and making $1 \mathrm{~mL}$ aliquots in $7.5 \mathrm{~mL}$ glass vials. The vials were partially closed with a rubber stopper (Figure 3.5 in Annexes) in order to permit water vapor from sublimation to escape. At the final, the vaccine had the IVS five times concentrated and the excipient solutions at half the stock solution concentration.

Five vials were prepared for each excipient solution. An additional of five vials with $1 \mathrm{~mL}$ were prepared with only the IVS diluted in purified water to achieve five times concentration. This unprotected formulation was used for comparison of results.

\subsection{Lyophilization process}

The lyophilization experiments were developed in a freeze dryer Edwards RC-300 (Edwards Vacuum, Crawley, West Sussex, UK). After preparation of the partially closed glass vials with vaccine formulations, the vials were disposed in the trays of the equipment. The trays were placed inside the freeze dryer and the protocol was started.

The protocol had 3 steps: freezing, primary drying and secondary drying. Several protocols were tested with the vaccine formulations in the freeze dryer, finally establishing the best lyophilization protocol. This protocol (Table 3.6) was used to freeze dry the different vaccine formulations.

Table 3.6: Description of the best lyophilization protocol.

\begin{tabular}{|c|c|c|}
\hline \multicolumn{1}{|c|}{ Step } & Temperature & Duration \\
\hline Freezing & $-42^{\circ} \mathrm{C}$ & 3 hours \\
\hline Primary Drying & $-40^{\circ} \mathrm{C}$ & 24 hours \\
& $-5^{\circ} \mathrm{C}$ & 96 hours \\
\hline Secondary Drying & $+25^{\circ} \mathrm{C}$ & 3 hours \\
\hline
\end{tabular}




\subsection{Visual aspects evaluation of lyophilized vials}

The lyophilized vials were visually evaluated using three parameters: color, integrity and uniformity. The color of the IVS without any excipient was white, so the excipient must not make modifications in the cake color to pass the color test. The cakes must have uniform mass distribution to pass the uniformity test. The cakes must not present cracks to pass the integrity test.

The cakes were reconstituted with purified water. Two other parameters were evaluated under this condition: time of reconstitution and $\mathrm{pH}$. The time of total reconstitution of cakes must not exceed one minute. The $\mathrm{pH}$ of the reconstituted cakes was also measured and must be between 6.8 and 8.5 (Brasil, 1988).

\subsection{Residual moisture test}

The residual moisture test was done by volumetric Karl Fischer titration in Titroline KF equipment (Schott SI Analytics, Mainz, Rhineland-Palatinate, Germany). The best three lyophilized vials of each formulation were selected for the test. The samples of each vial were weighted and titrated in the Karl Fischer equipment. The residual moistures as well as the mean values were calculated. The residual moisture must not pass $3 \%$ for the lyophilized rabies vaccine (Brazil, 1988).

\section{Results and Discussion}

\subsection{Kinects results and comparisons}

The main objective of the development experiments was to evaluate the best viral production. However it was important to obtain growth curves of the four spinners in order to analyze and compare the infected cultures with the negative control in terms of kinects, specific growth rate and metabolites consumption and production. This development experiment was able to tell the influence of the different $\mathrm{MOI}$ in the spinners and compare the results with a not infected spinner.

\subsubsection{BHK-21 cell production}

After 10 days of experiment, the growth curves for the fours spinners were measured in terms of viable cells (Figure 4.1). 


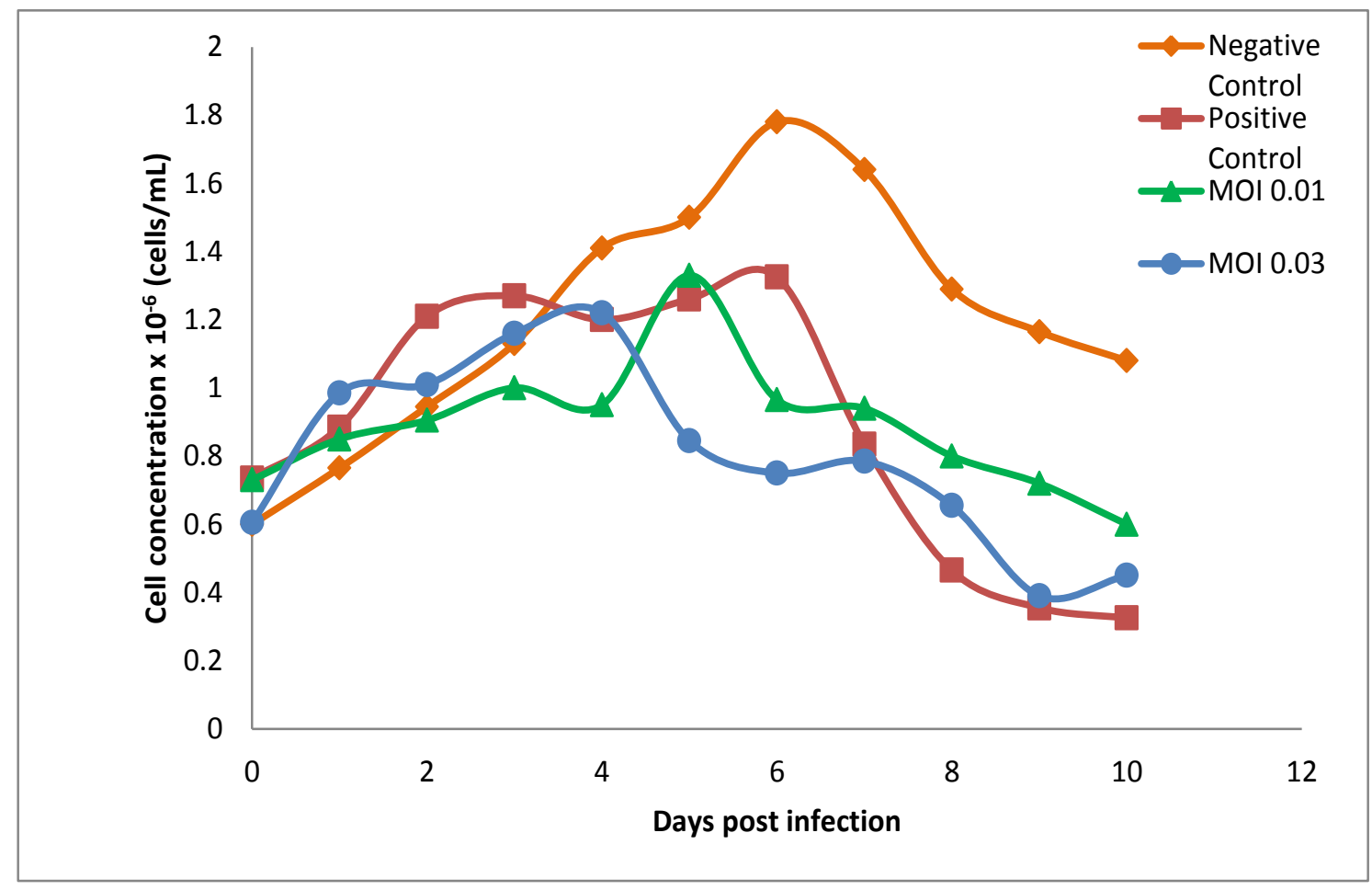

Figure 4.1: Cell growth curves obtained for the four spinners cultivation in development experiments. After 10 days of infection, the negative control of assay achieved maximum cell concentration of 1.78 million cells $/ \mathrm{mL}$ (viable cells) at $6 \mathrm{dpi}$ (days post infection). The positive control achieved maximum cell concentration of 1.33 million cells $/ \mathrm{mL}$ (viable cells) at $6 \mathrm{dpi}$. The spinner $\mathrm{MOI} 0.01$ reached a maximum of 1.33 million cells $/ \mathrm{mL}$ (viable cells) at $5 \mathrm{dpi}$. The spinner $\mathrm{MOI} 0.03$ achieved its maximum with 1.22 million cells $/ \mathrm{mL}$ (viable cells) at $4 \mathrm{dpi}$.

In terms of cell production, the negative control of assay achieved maximum cell concentration of 1.81 million cells $/ \mathrm{mL}$ (total cells) and 1.78 million cells $/ \mathrm{mL}$ (viable cells) at $6 \mathrm{dpi}$. After $6 \mathrm{dpi}$, the growth rate began to decrease, reaching 1.08 million viable cells $/ \mathrm{mL}$ at the end of the assay. The cell concentration obtained in negative control was similar to normal cell production at TECPAR (data not showed).

The positive control of the assay was infected with $15 \mathrm{~mL}$ of virus. Maximum cell concentration was 1.43 million cells $/ \mathrm{mL}$ (total cells) and 1.33 million cells $/ \mathrm{mL}$ (viable cells) at $6 \mathrm{dpi}$. After $6 \mathrm{dpi}$, the growth rate began to rapidly decrease, reaching 355,000 viable cells $/ \mathrm{mL}$ at the end of the assay. The growth curve had a slightly decrease between 3 and $4 \mathrm{dpi}$, probably because of intense virus production, restarting the growth between 4 and 5 dpi.

The spinner with $\mathrm{MOI} 0.01$ was infected with $10 \mathrm{~mL}$ of virus. Cell concentration reached a maximum of 1.48 million cells $/ \mathrm{mL}$ (total cells) and 1.33 million cells $/ \mathrm{mL}$ (viable cells) at 5 dpi. This growth achieved a peak at $5 \mathrm{dpi}$ and 
after this began to decrease reaching 600,000 viable cells $/ \mathrm{mL}$ at the end of the assay.

The spinner with $\mathrm{MOI} 0.03$ was infected with $30 \mathrm{~mL}$ of virus. Cell concentration achieved its maximum with 1.29 million cells $/ \mathrm{mL}$ (total cells) and 1.22 million cells $/ \mathrm{mL}$ (viable cells) at $4 \mathrm{dpi}$. After $4 \mathrm{dpi}$, the growth rate rapidly decreased at $5 \mathrm{dpi}$, stabilized at 6 and $7 \mathrm{dpi}$ and then decreased again, reaching 450,000 viable cells $/ \mathrm{mL}$ at the end of the assay.

The peak of growing for the different infected cultures was different: 6 dpi for positive control, $5 \mathrm{dpi}$ for $\mathrm{MOI} 0.01$ and $4 \mathrm{dpi}$ for $\mathrm{MOI} 0.03$. The peak of $\mathrm{MOI} 0.03$ was achieved faster probably due the virus concentration that was the highest and started to make effect on the culture earlier than the others. Nevertheless, the infected cultures achieved similar peaks of concentration and the oscillations of growing were practically constant.

Perrin and collaborators (1995) used two different $2 \mathrm{~L}$ bioreactors (1.3 L working volume) to produce rabies vaccine using BHK-21 cells in perfusion mode. The maximum cell density in the two bioreactors was close to 6 million cells $/ \mathrm{mL}$. Kallel and collaborators (2002) also developed an experiment for producing rabies vaccines in BHK-21 cells in $250 \mathrm{~mL}$ spinner and $2 \mathrm{~L}$ (1.3 L working volume) bioreactor. The maximum cell concentration obtained was 2 million cells $/ \mathrm{mL}$ in noninfected spinners and 1.2 to 1.6 million cells $/ \mathrm{mL}$ in infected spinners. In bioreactors, the maximum cell density achieved 3 million cells $/ \mathrm{mL}$ in batch mode.

The results for the four spinners were similar to those obtained by Kallel and collaborators (2002) although the four spinners used a higher amount of medium volume. Also cultures with the same volume in bioreactor had better cell production than spinner. This happened because the bioreactors possess better controls for temperature, dissolved oxygen, $\mathrm{pH}$ and agitation. So then, using bioreactors with the same volume of the experiment $(1.5 \mathrm{~L})$ would increase cell production. Additionally, using a perfusion system coupled with bioreactor would imply in even better results.

Using the formula described in Figure 3.2, the specific growth rate $(\mu)$ could be calculated for each dpi (Table 4.1). 
Table 4.1: Maximum specific growth rate for the four spinners.

\begin{tabular}{|c|c|c|}
\hline Spinner & $\mu_{\max }\left(h^{-1}\right)$ & dpi of $\mu_{\max }$ \\
\hline Neg. Control & 0.010 & $1 \mathrm{dpi}$ \\
\hline Pos. Control & 0.013 & $2 \mathrm{dpi}$ \\
\hline MOI 0.01 & 0.014 & $5 \mathrm{dpi}$ \\
\hline MOI 0.03 & 0.020 & $1 \mathrm{dpi}$ \\
\hline
\end{tabular}

A characteristic of animal cells like BHK-21 is that, even under optimized conditions of growing, present a low specific growth rate, between $0.01 \mathrm{~h}^{-1}$ and 0.05 $h^{-1}$. That $\mu$ is significantly lower than specific growth rates presented by microorganisms thus making the industrial process costlier (Tonso, 2000).

The four spinners achieved a $\mu_{\max }$ compatible with the optimized cultures although the spinners had poor process controlling which means that the cultures grown satisfactorily.

\subsubsection{Viability of cell cultures}

The viability was obtained in percentage, dividing viable cells by total cells and multiplying 100 times. From the results, the highest, the lowest and the mean value for viability were obtained (Table 4.2).

Table 4.2: Rate of cell culture viabilities for the four spinners. Between brackets is the days post infection (dpi) where the viability was achieved

\begin{tabular}{|c|c|c|c|}
\hline Spinner & Highest viability & Lowest viability & Mean viability \\
\hline Neg. Control & $98.3 \%$ (6dpi) & $88.2 \%$ (0dpi) & $95.4 \%$ \\
\hline Pos. Control & $96.2 \%$ (3dpi) & $66 \%$ (8dpi) & $87.7 \%$ \\
\hline MOI 0.01 & 95.4\% (7dpi) & 85.6\% (8dpi) & $91.1 \%$ \\
\hline MOI 0.03 & 97.5\% (3dpi) & 75.7\% (8dpi) & $90.8 \%$ \\
\hline
\end{tabular}

The viability of negative control was the highest because of the absence of virus. Therefore cell concentration was limited by other factors like absence of gas, $\mathrm{pH}$ and temperature control, agitation and accumulation of some metabolites and debris that could interfere in cell growing.

The virus does not kill the cell because the new virions are released outside by budding. Not infected cells replicate normally although, one infected cell does not replicate anymore, only producing more virus until its death. So then, with a lower quantity of virus as inoculum, the tendency is to achieve a better viability 
because the cells will take a longer time to become infected and die. The spinner with $\mathrm{MOI} 0.01$ has the best viability among infected spinners because of the lower quantity of virus inoculated.

Chapman and collaborators (1973) studied the viability of BHK-21 cells infected with rabies virus and kept in two temperatures, $33^{\circ} \mathrm{C}$ and $36^{\circ} \mathrm{C}$. $\mathrm{MOI} 0.05$ was used in this experiment, corresponding to $1 \%$ of the final volume of the vessel, just like the positive control. The viability of cells after infection at $36^{\circ} \mathrm{C}$ decreased from 3 dpi reaching almost $0 \%$. However, the viability of infected cells at $33^{\circ} \mathrm{C}$ remained above $90 \%$, just as founded in the development experiment.

\subsubsection{Metabolites consumption and production}

Daily samples were taken and evaluated in terms of glucose consumption and lactate production for the four spinners (Table 4.3).

Table 4.3 Minimum glucose concentration and maximum lactate production for the culture cells in four spinners during the 10 days of infection. Between brackets is the days post infection (dpi) where the concentration was obtained.

\begin{tabular}{|c|c|c|}
\hline Spinner & Min. Glucose Conc. & Max. Lactate Conc. \\
\hline Neg. Control & $1.20 \mathrm{~g} / \mathrm{L}$ (8dpi) & $2.33 \mathrm{~g} / \mathrm{L}$ (8dpi) \\
\hline Pos. Control & $2.63 \mathrm{~g} / \mathrm{L}$ (6dpi) & $1.42 \mathrm{~g} / \mathrm{L}$ (7dpi) \\
\hline MOI 0.01 & $2.04 \mathrm{~g} / \mathrm{L}$ (5dpi) & $1.81 \mathrm{~g} / \mathrm{L}(5 \mathrm{dpi})$ \\
\hline MOI 0.03 & $2.78 \mathrm{~g} / \mathrm{L}(8 \mathrm{dpi})$ & $1.14 \mathrm{~g} / \mathrm{L}(5 \mathrm{dpi})$ \\
\hline
\end{tabular}

Animal cells need glucose and glutamine as carbon sources. In the glucose metabolism practically all of glucose is converted in lactose. Thus, the relation between glucose consumption and lactate production represent important parameters for process monitoring and providing information about the metabolic flow inside the cells (Zeng et al., 1998; Tonso, 2000).

Cruz and collaborators (2000) studied the effects of lactate inhibition on BHK cells. When lactate concentration achieved $28 \mathrm{mM}$ (which correspond to 2.52 $\mathrm{g} / \mathrm{L})$, cell growth was reduced. Therefore in none of the spinners, the lactate reached a limiting concentration. Also, in none of the spinners the glucose was totally consumed. 
Usually the cultures in $1.5 \mathrm{~L}$ spinner are made with $1.25 \mathrm{~L}$ working volume. The volume used in the developed experiments was $1.5 \mathrm{~L}$. This was an attempt of increase the cell production, providing more carbon source to cells. Unfortunately the cell production in the experiment was close to cell concentrations usually obtained in $1.25 \mathrm{~L}$. Furthermore, the glucose remained with high concentration in positive control and $\mathrm{MOI} 0.03$ spinners, which means that the medium change during days post infection threw away medium that was still good for cell growing, generating a waste of money.

\subsection{Infection rate results}

The infection rate is a qualitative method to evaluate the behavior of virus inside the cells during the cultivation. Table 4.4 summarizes the results for infection rate found in the three infected spinners. Figure 4.2 in Annexes shows examples of classification of infection rate.

Table 4.4: Infection rates of virus inside cells.

\begin{tabular}{|c|c|c|c|}
\hline Dpi & Pos. Control & MOI 0.01 & MOI 0.03 \\
$\mathbf{1}$ & Class 1 & Class 1 & Class 1 \\
$\mathbf{2}$ & Class 3 & Class 2 & Class 4 \\
$\mathbf{3}$ & Class 4 & Class 4 & Class 4 \\
$\mathbf{4}$ & Class 4 & Class 4 & Class 4 \\
$\mathbf{5}$ & Class 4 & Class 4 & Class 4 \\
$\mathbf{6}$ & Class 4 & Class 4 & Class 4 \\
$\mathbf{7}$ & Class 4 & Class 4 & Class 3 \\
$\mathbf{8}$ & Class 3 & Class 4 & Class 3 \\
$\mathbf{9}$ & Class 3 & Class 4 & Class 3 \\
\hline $\mathbf{1 0}$ & Class 3 & Class 4 & Class 4 \\
\hline
\end{tabular}

However, the infection rate does not reflect on the production of virus inside the cells and the quality of virus produced. The direct immunofluorescence is one tool for process control and only classifies the infection rate inside the cells. This technique can be used to predict on which dpi the harvests can be initiated. Normally when the culture reaches Class 4 it means that harvests can be made. This happened for all spinners at $3 \mathrm{dpi}$, and that was the day that harvests were initiated. 
From the results it can be concluded that the inoculum with the lowest concentration of virus took a longer time to achieve Class 4 (more than $75 \%$ of fluorescent focuses). Also, oscillations between Class 3 and Class 4 are normal depending if cells are replicating, which would imply in less fluorescent focuses, or producing virus, which would imply in more fluorescent focuses.

\subsection{Virus titration results}

The virus titration is an important tool to evaluate viral production and quality in several stages of vaccine production (Fuches, 2010). It is a relatively fast in vitro test (when compared to in vivo tests) to evaluate the infection of virus produced in other cells and compare the results with a standard virus. Butantan Institute in Brazil made a comparative study which showed a good correlation between the virus titration results and the potency results performed in mice but the data was not published (Fuches, 2010).

The virus samples from the three infected spinners collected during the ten days of infection were titrated (Figure 4.3). Also, in Annexes shows examples of field classification in virus titer determination (Figure 4.4).

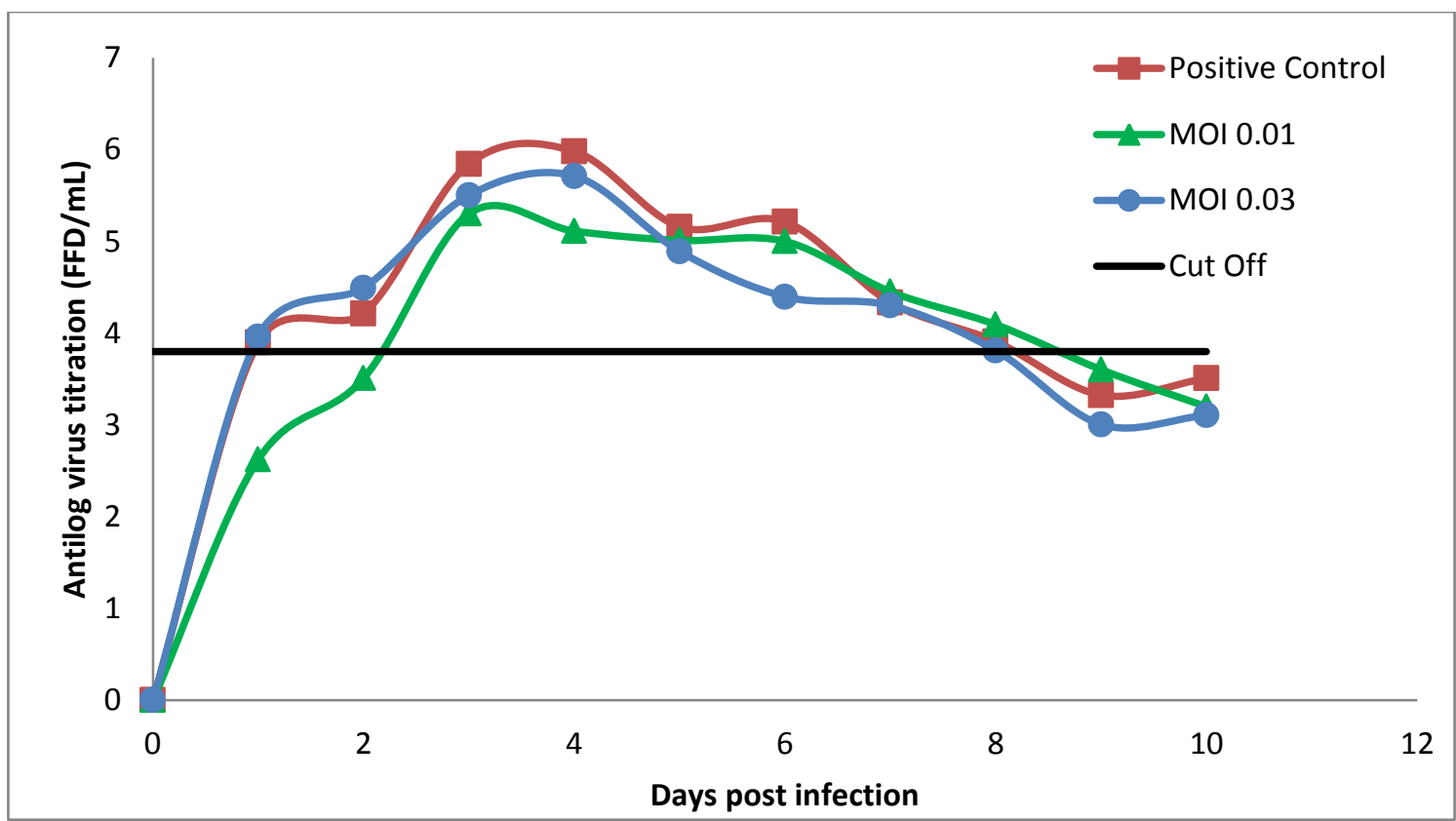

Figure 4.3: Virus titration curves for the three infected spinners Only harvests above cut off are used for rabies vaccine production. The maximum titration value reached by positive control was $105.98 \mathrm{FFD} / \mathrm{mL}$ at $4 \mathrm{dpi}$. The maximum for $\mathrm{MOI}$ 0.01 was $105.37 \mathrm{FFD} / \mathrm{mL}$ at $3 \mathrm{dpi}$ and for $\mathrm{MOI} 0.03$ was $105.77 \mathrm{FFD} / \mathrm{mL}$ at $4 \mathrm{dpi}$. The best graphic area above cut off means the best inoculum. In this case, the best inoculum corresponds to the positive control. 
The titration for the standard virus was $10^{5.37} \mathrm{FFD} / \mathrm{mL}$. The maximum titration value reached by positive control was $10^{5.98} \mathrm{FFD} / \mathrm{mL}$ at 4 dpi. The maximum for $\mathrm{MOI} 0.01$ was $10^{5.37} \mathrm{FFD} / \mathrm{mL}$ at $3 \mathrm{dpi}$ and for $\mathrm{MOI} 0.03$ was $10^{5.77}$ $\mathrm{FFD} / \mathrm{mL}$ at 4 dpi. Harvests of virus from infected spinners were made from 3 dpi to $8 \mathrm{dpi}$ and kept in ultrafreezer at $-80^{\circ} \mathrm{C}$.

TECPAR uses harvests from the bioreactor to produce rabies vaccine. These harvests are also titrated in order to evaluate the virus production and determine the best results. After several attempts to produce a vaccine with great potency using different titers, it was established a cut off at $10^{3.8} \mathrm{FFD} / \mathrm{mL}$ and harvests with virus titer lower than cut off should not be used to produce rabies vaccine (no published data).

Same reasoning was applied in the spinner cultures. The best viral inoculum determination took into account how many harvests were above the cut off and among these harvests which present the best results or in a better way, which inoculum obtained the larger graphic area above cut off.

Among the days where harvests occurred, all of the infected spinners had six harvests above the cut off. However, positive control and MOI 0.03 obtained two more harvests above the cut off that were not collected. Between the harvests above cut off, it can be seen that the positive control have the largest graphic area above cut off.

Based on all information showed and calculated it can be concluded that positive control is the best inoculum for spinner infection. This viral inoculum is made by adding a viral volume correspondent to $1 \%$ of the volume of the vessel utilized in the experiment is the best way to infected one BHK-21 culture with rabies virus.

\subsection{Lyophilization results}

\subsubsection{Visual aspects evaluation}

After the IVS was formulated with different excipients and aliquoted in the glass vials, the lyophilization protocol was started and the resultant lyophilized cakes for the twelve formulations were obtained (Figures 4.5 and 4.6). 


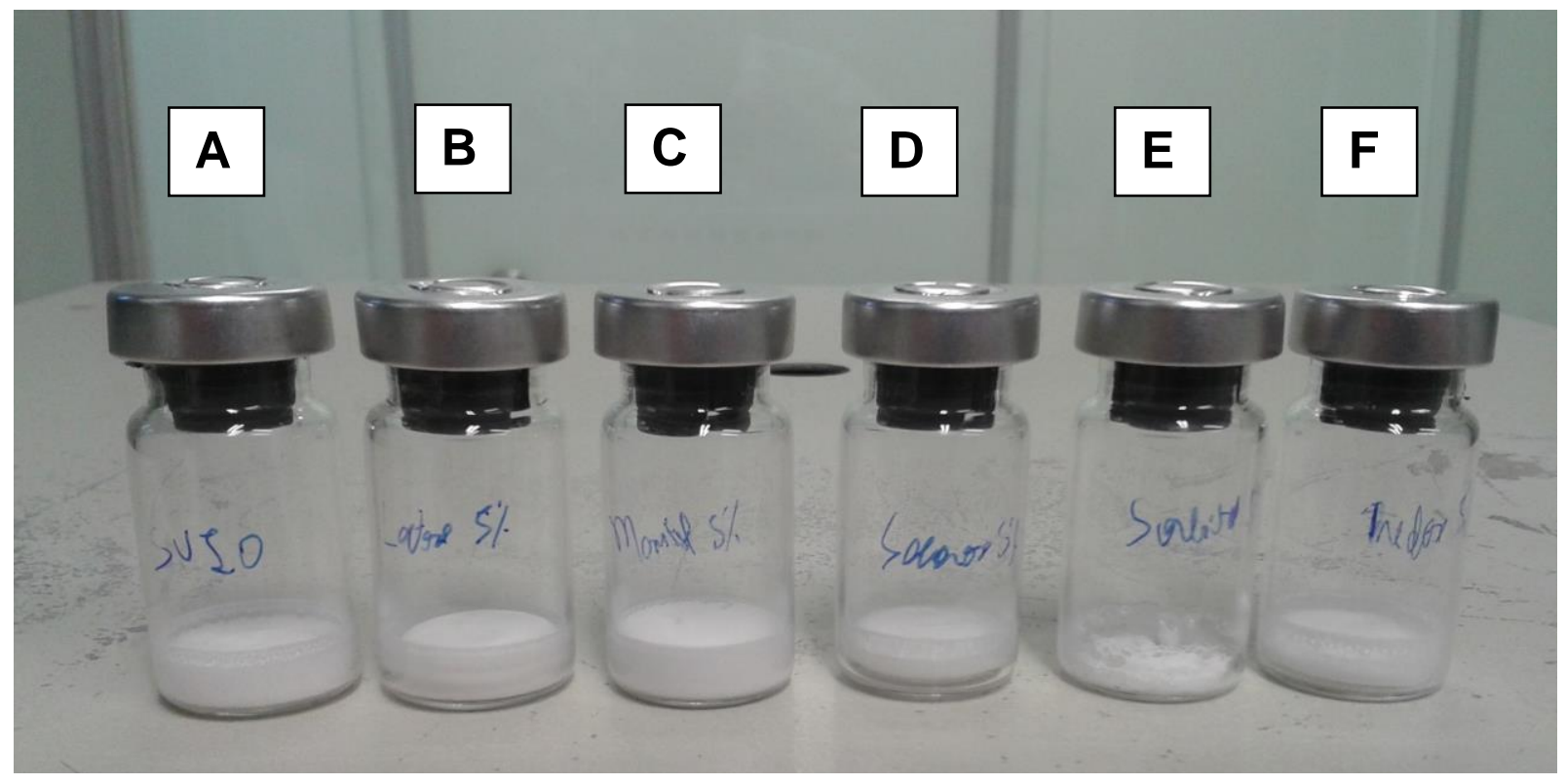

Figure 4.5: Lyophilized cakes part one.

$A=$ IVS without excipient; $B=$ Lactose $5 \%$; $C=$ Mannitol 5\%; $D=$ Sucrose $5 \%$; $E=$ Sorbitol $5 \%$; $F=$ Trehalose $5 \%$. All the sugars presented good cakes as well as mannitol, the IVS without excipient formed a heterogeneous cake and the sorbitol cake collapsed.

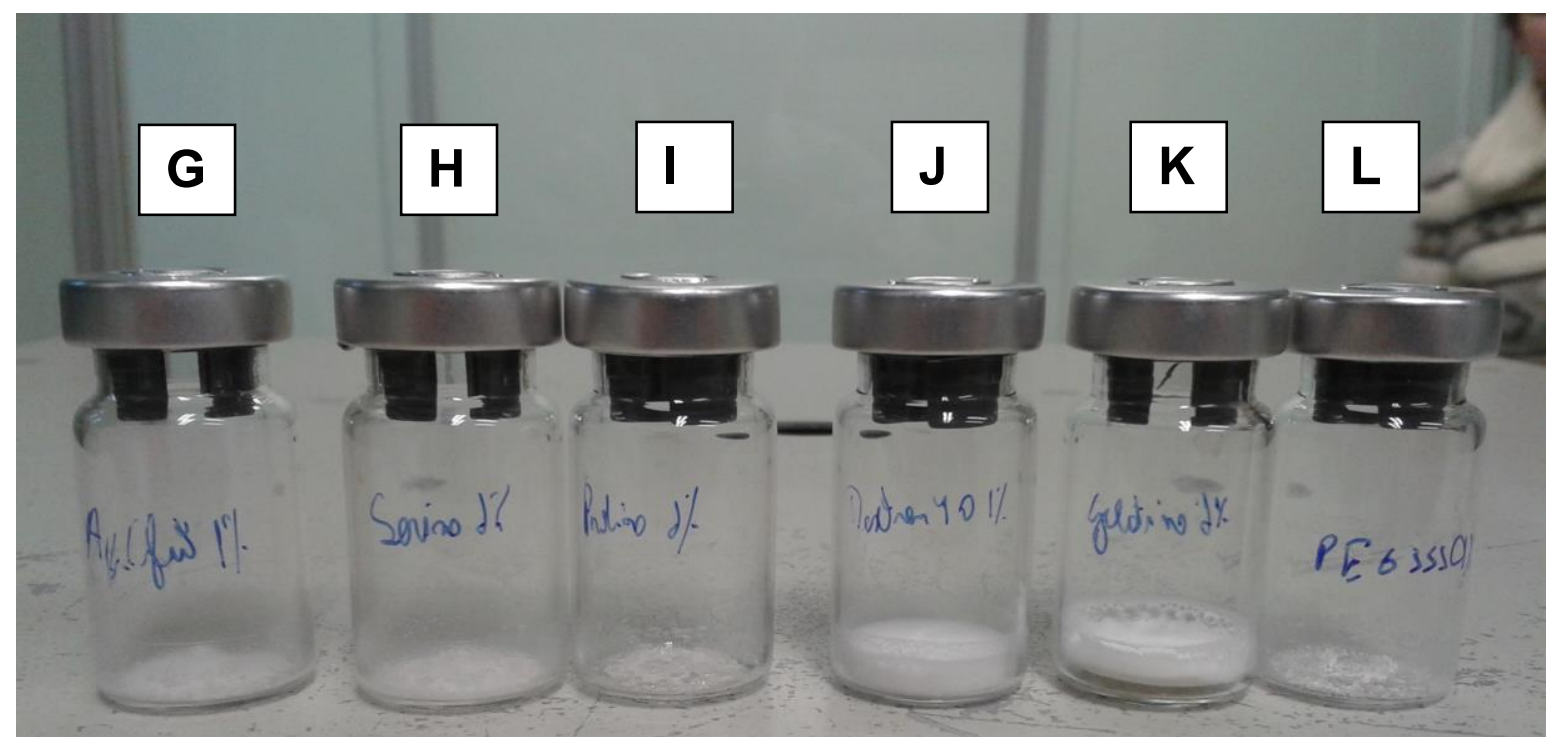

Figure 4.6: Lyophilized cakes part two.

$\mathrm{G}=$ Glutamic acid 1\%; $\mathrm{H}=$ Serine 1\%; I= Proline 1\%; J= Dextran $401 \%$; $\mathrm{K}=$ Gelatin $1 \%$ and $L=P E G 33501 \%$. All the amino acids formed collapsed cakes, as well as PEG3350, dextran 40 formed an excellent cake and gelatin presented a heterogeneous cake.

The lyophilized cakes were visually evaluated in terms of the lyophilized cakes in terms of color, uniformity, integrity (Table 4.5). 
Table 4.5: Visual aspects evaluation of lyophilized cakes. The " $X$ " symbolizes cakes that pass the tests.

\begin{tabular}{|c|c|c|c|}
\hline Excipient & Color & Uniformity & Integrity \\
\hline Pure IVS & $X$ & & $X$ \\
\hline Sucrose & $\mathrm{X}$ & $\mathrm{X}$ & $\mathrm{X}$ \\
\hline Trehalose & $\mathrm{X}$ & $\mathrm{X}$ & $\mathrm{X}$ \\
\hline Lactose & $\mathrm{X}$ & $\mathrm{X}$ & $X$ \\
\hline Sorbitol & $\mathrm{X}$ & & \\
\hline Mannitol & $\mathrm{X}$ & $\mathrm{X}$ & $\mathrm{X}$ \\
\hline Proline & $\mathrm{X}$ & & \\
\hline Serine & $\mathrm{X}$ & & \\
\hline Glutamic Acid & $\mathrm{X}$ & & \\
\hline Dextran 40 & $\mathrm{X}$ & $\mathrm{X}$ & $\mathrm{X}$ \\
\hline PEG 3350 & $\mathrm{X}$ & & \\
\hline Gelatin & $\mathrm{X}$ & & $\mathrm{X}$ \\
\hline
\end{tabular}

The lyophilization of amino acids as excipients did not produce good cakes. The samples presented collapsed during lyophilization (process also known as melt back). The same phenomenon happened with sorbitol. PEG 3350 cakes melt back too but appeared drier than sorbitol and amino acids cakes. IVS and gelatin did not pass the uniformity test because of the bubbles presented.

All excipients did not aggregated color to the cake and passed the color test. The best excipients in this step were: sucrose, lactose, trehalose and dextran.

After reconstituting the vaccine with purified water, two parameters were evaluated: time of reconstitution and $\mathrm{pH}$ of the reconstituted cakes (Table 4.6).

Table 4.6: Time and $\mathrm{pH}$ evaluation of reconstituted cakes. The " $X$ " symbolizes formulations that achieved the specified time of reconstitution.

\begin{tabular}{|c|c|c|}
\hline Excipient & Time of reconstitution & Final pH \\
\hline Pure IVS & X & 7.58 \\
\hline Sucrose & $\mathrm{X}$ & 7.52 \\
\hline Trehalose & $\mathrm{X}$ & 7.56 \\
\hline Lactose & $\mathrm{X}$ & 7.54 \\
\hline Sorbitol & $\mathrm{X}$ & 7.55 \\
\hline Mannitol & $\mathrm{X}$ & 7.58 \\
\hline Proline & $\mathrm{X}$ & 7.56 \\
\hline Serine & $\mathrm{X}$ & 7.32 \\
\hline Glutamic Acid & $\bar{X}$ & 3.47 \\
\hline Dextran 40 & $\bar{X}$ & 7.56 \\
\hline PEG 3350 & $\mathrm{X}$ & 7.57 \\
\hline Gelatin & & 7.4 \\
\hline
\end{tabular}


The only excipient that did not pass the time of reconstitution test was gelatin which did not solubilize in purified water in less than a minute. Although the other excipients had passed, the time of reconstitution was better in pure IVS, sucrose, mannitol and dextran. Lactose and trehalose took a while longer to become homogenized. The excipients with worse cakes, like all amino acids and PEG, took more time for reconstitution but achieved total homogenization in less than one minute.

The Brazilian regulatory agency (MAPA) demands that the reconstituted vaccine have $\mathrm{pH}$ between 6.8 and 8.5 (Brasil, 1988). The only excipient that did not pass the $\mathrm{pH}$ test was glutamic acid which turned the vaccine more acid than recommended.

\subsubsection{Residual moisture evaluation}

Three samples were measured by Karl Fischer volumetric titration in terms of residual moisture and the mean moisture was calculated (Table 4.7).

Table 4.7: Residual moisture results for lyophilized cakes.

\begin{tabular}{|c|c|c|c|c|}
\hline Excipient & RM1 & RM2 & RM3 & Mean Residual Moisture \\
\hline Pure IVS & 4.16 & 3.99 & 2.73 & $3.63 \% \pm 0.78 \%$ \\
\hline Sucrose & 2.30 & 2.98 & 2.32 & $2.53 \% \pm 0.39 \%$ \\
\hline Trehalose & 2.51 & 3.33 & 3.18 & $3.01 \% \pm 0.44 \%$ \\
\hline Lactose & 2.34 & 2.86 & 3.28 & $2.83 \% \pm 0.47 \%$ \\
\hline Sorbitol & $\mathrm{NC}^{*}$ & $\mathrm{NC}^{*}$ & $\mathrm{NC}^{*}$ & $\mathrm{NC}^{*}$ \\
\hline Mannitol & 1.93 & 2.78 & 2.72 & $2.48 \% \pm 0.47 \%$ \\
\hline Proline & $\mathrm{NC}^{*}$ & $\mathrm{NC}^{*}$ & $\mathrm{NC}^{*}$ & $\mathrm{NC}^{*}$ \\
\hline Serine & $\mathrm{NC}^{*}$ & $\mathrm{NC}^{*}$ & $\mathrm{NC}^{*}$ & $\mathrm{NC}^{*}$ \\
\hline Glutamic Acid & $\mathrm{NC}^{*}$ & $\mathrm{NC}^{*}$ & $\mathrm{NC}^{*}$ & $\mathrm{NC}^{*}$ \\
\hline Dextran 40 & 3.15 & 2.95 & 2.74 & $2.95 \% \pm 0.21 \%$ \\
\hline PEG 3350 & $\mathrm{NC}^{*}$ & $\mathrm{NC}^{*}$ & $\mathrm{NC}^{*}$ & $\mathrm{NC}^{*}$ \\
\hline Gelatin & 3.42 & 3.10 & 2.85 & $3.12 \% \pm 0.29 \%$ \\
\hline
\end{tabular}

${ }^{*} \mathrm{NC}$ : not calculated

The Karl Fischer titration is done injecting a known mass in the equipment and analyzing the quantity of Karl Fischer reagent necessary to react with residual water in the sample. Cakes obtained for the amino acids and PEG 3350 could not be removed from lyophilized vials for injection in the titration equipment because 
the cakes were melt back and difficult to collect. Therefore residual moistures of these excipients could not be calculated.

The Brazilian regulatory agency (MAPA) recommends that residual moisture do not pass 3\% (Brasil, 1988). The IVS without excipient addition and gelatin did not pass the test. The trehalose was slightly above the recommended but since the test is influenced by many factors (temperature, operating time, air humidity), it can be said that trehalose passed the test and furthermore the lyophilized trehalose cake will be reevaluated. The other excipients analyzed had residual moisture under the regulatory claims.

\subsubsection{Best excipients selection}

The IVS without any excipient formed a cake that passed in the visual aspects tests and almost passed the residual moisture test. This was possible because the IVS is 10 times concentrated. Even with the 5 times buffer exchange, there could still be traces of sugar, fetal bovine serum, amino acids and other metabolites that probably stabilized the IVS during the lyophilization. Lang and Winter (2009) demonstrated that sodium chloride interfere in lyophilization in concentrations superior to $60 \mathrm{mmol} / \mathrm{L}$ by aggregating molecules. The sodium chloride concentration on NT buffer is $50 \mathrm{mmol} / \mathrm{L}$, so the presence of this salt only improves the tonicity of the vaccine.

The amino acids cakes melt back. It occurred probably due theirs ineffectiveness in protecting the IVS when used as only excipient, despite the excipients already present in the pure IVS. It use can have better results when associated with excipients of a different kind.

The book Laboratory Techniques in Rabies describes two protocols utilizing gelatin as excipient. In this work gelatin provided good cakes but after reconstitution it did not homogenized within the desired time which discarded the use of this excipient in future in vivo tests.

Trehalose was described as a good cryo and lyoprotector by Gupta and collaborators (1996) and Sarkar and collaborators (2003) for respiratory syncytial virus vaccine and pest des petites ruminants vaccine respectively. Caricati (2010) also tested different excipients for rabies vaccine lyophilization, obtaining interesting results for trehalose, sucrose and PEG 3350. The present work also presented good results for trehalose and sucrose in terms of visual aspects and residual moisture. However PEG 3350 which is very used as stabilizing agent in 
lyophilization had poor results which were a disappointing result. PEG performance can also be improved if coupled with other excipients.

Lang and Winter (2009) also tested mannitol as excipient. When used alone mannitol presented good results for appearance and residual moisture. When coupled with trehalose, the resultant cake had a very robust crystalline matrix leading to a more elegant final product and enabling shorter drying times. Based on these results, in next lyophilization experiments mannitol and trehalose could be coupled together to test the resultant cake.

Sucrose, at concentrations 1 to $68 \%$ has quite frequently been used for the cryopreservation of microorganisms (Hubálek, 2003). Law and Hull (1968) tested the stabilizing effect of sucrose for the respiratory syncytial virus and its infectivity, obtaining good results. Sehgal and Das (1975) studied the effect of freezing upon the bean mosaic virus using sucrose as stabilizer and also obtained good results.

Dextran, as well as sorbitol and mannitol are inert excipients. They provide elegance to lyophilized cakes because easily crystallize under low temperatures and are used in biopharmaceutical vaccines that use lower doses per vial and consequently have lower mass. In these cases, the inert excipients provide more volume and can be coupled with amorphous excipients generating a two phase solid: one amorphous with the active principle and one crystalline with the inert excipient (Caricati, 2010). The use of dextran and mannitol in the present work provided cakes with good appearance but it is necessary to know if the antigen was protected during the lyophilization experiment. However sorbitol cakes collapsed and further investigation will occur to understand the problems involved.

In summary, the best excipients tested were sucrose, trehalose, lactose, mannitol and dextran 40. Formulations with these excipients can be tested in vivo to evaluate if the viral proteins still active and the vaccine have potency. Also a formulation with the clarified IVS five times concentrated without excipients addition should be tested in vivo to verify if the residual metabolites alongside the buffer exchange are sufficient to maintain the rabies vaccine potency. Based on that, five excipients were selected for posterior in vivo test: pure IVS, sucrose, trehalose, mannitol and dextran 40. Also, the cost of excipients must be taken into account to determine the best excipients. Within the five best excipients, sucrose is the cheapest and dextran 40 is the most expensive, so it is necessary that the best excipient also doesn't increase the final price of the product enabling the implementation of the lyophilization technique and scale up of the process. 


\section{Conclusions}

At the final of the development experiment the growth curves for four BHK21 cells cultivated in $1.5 \mathrm{~L}$ spinners under different viral inocula were determined. Parameters like kinects, viability, infection rate, and virus titration were calculated and discussed in order to comprehend the cell growth before and after the infection. The maximum specific growth rate of the four spinners was in accordance with those obtained in optimized animal cell cultures. The metabolic analysis showed that in none of the days glucose was absent and lactate production did not achieve a limiting concentration. The infection rate established the third day post infection as beginning of infected culture harvests. The virus titration showed that positive control had the best graphic area above the cut off, determining that positive control ( $1 \%$ of spinner volume) was the best viral inoculum.

The best lyophilization protocol was determined and several excipients were tested with this protocol. The IVS without any excipient alongside trehalose, sucrose, lactose, mannitol and dextran 40 presented lyophilized cakes with the best appearance. Serine, glutamic acid, proline, PEG 3350 and sorbitol cakes collapsed during lyophilization. In the reconstitution tests only gelatin was reproved and in the $\mathrm{pH}$ tests only glutamic acid was reproved. Sucrose, mannitol, trehalose, lactose and dextran 40 passed the residual moisture test. The lyophilization experiments selected five excipients for posterior in vivo tests: pure IVS, sucrose, trehalose, mannitol and dextran 40 .

\section{Perspectives}

Based on the results obtained in this experiment, future work can be done: the development experiment will be repeated with the same conditions to compare the results; a pool of positive control harvests will be made and inactivated with beta-propiolactone; this inactivated viral suspension will be concentrated ten times and the medium will be exchanged with NT buffer for lyophilization experiments; the IVS will be formulated and freeze dried using the same work protocol; the lyophilized vials will be tested for all in vitro and in vivo tests demanded by the Brazilian regulatory agency (MAPA) with the excipients selected and combinations of these excipients. Also an economical study will be made for the best in vivo excipients in order to determine the viability of industrial application of the lyophilization technique. 


\section{Annexes}

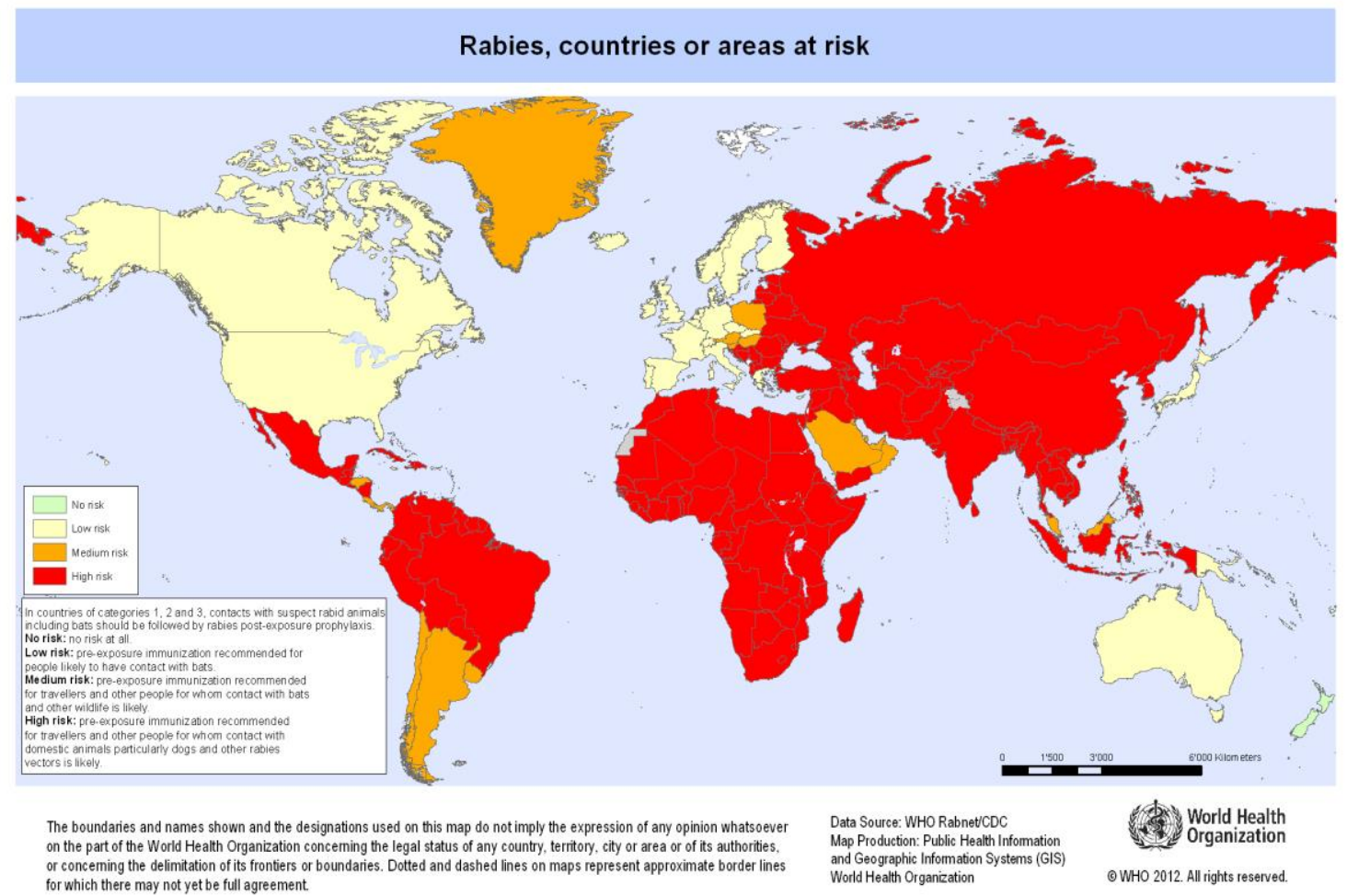

Figure 1.1: Rabies wide world distribution and risk exposition. Data source: WHO, 2012.

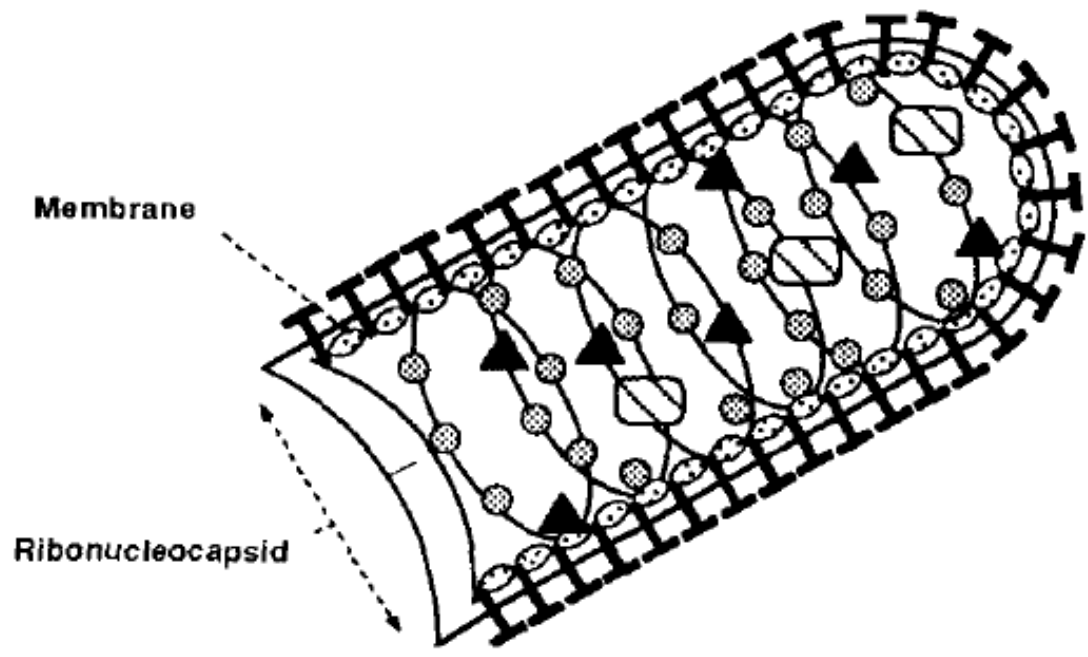

2) Nucleoprotein

Ahoephoprotein

(.) Matrix protein

Glycoprotein

D) RNA-polymerase

Figure 1.2: Structure of rabies virus (RABV). Adapted from Bourhy et al. (1990). 


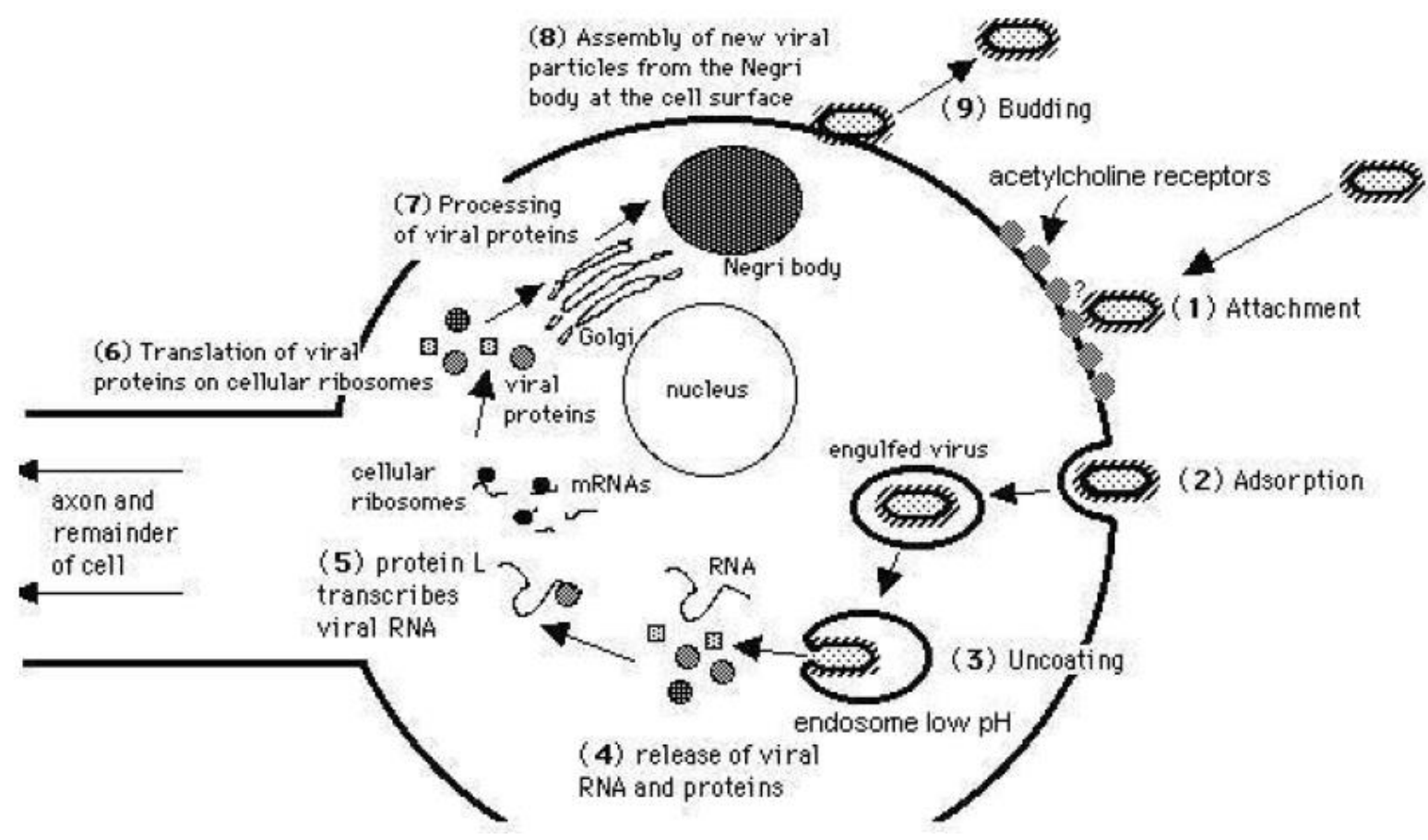

Figure 1.3: Cycle of viral infection and replication of RABV inside one neuron. Adapted from Mazarakis et al. (2001).

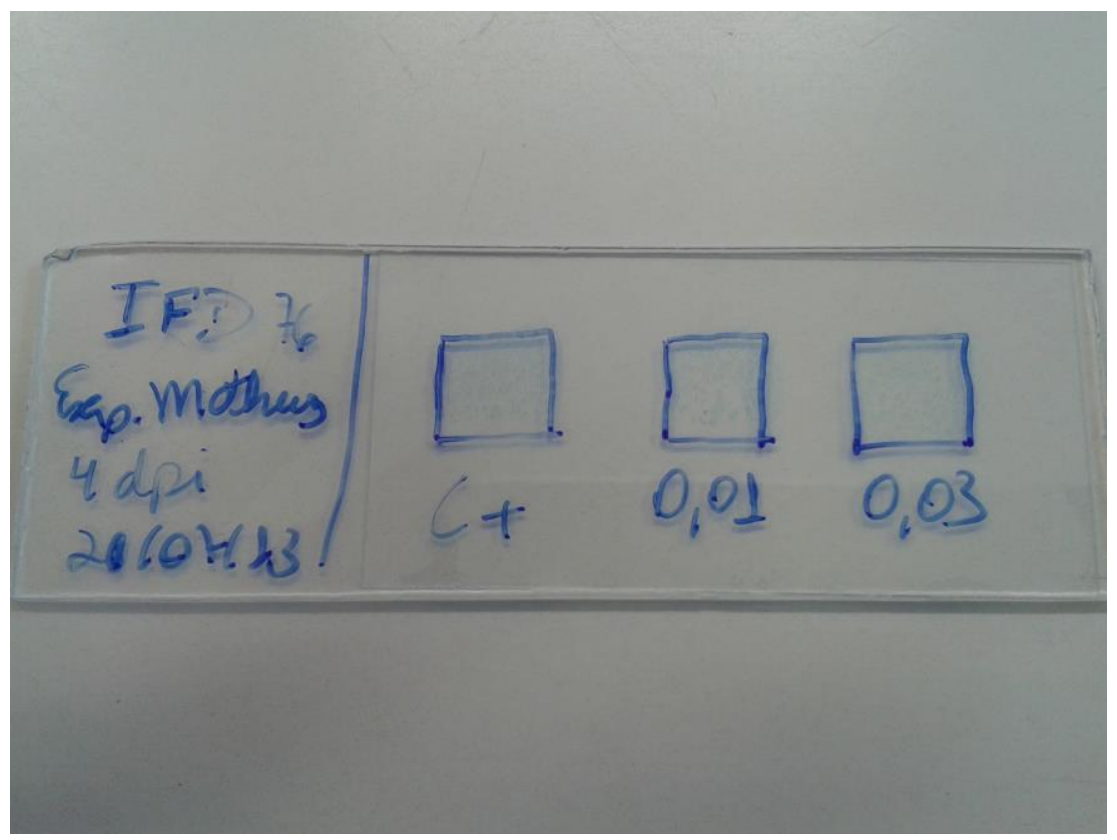

Figure 3.3: Direct immunofluorescence assay ready for reading. Each blue square represents one sample. The markings are drawn on the opposite side of the lamina and the reading is done with the cell side upturned. 
Table 3.2: Scheme of samples and dilutions for virus titration in 96 wells microplate.

The sample "0" was applied without dilution. CC means Cell Control where no virus was added. Examples: "Std -2" signifies the standard diluted 100 times (10-2); "4dpi -4 " signifies the sample from 4 dpi diluted 10000 times $\left(10^{-4}\right)$.

\begin{tabular}{|c|c|c|c|c|c|c|c|c|c|c|c|c|}
\hline & 1 & 2 & 3 & 4 & 5 & 6 & 7 & 8 & 9 & 10 & 11 & 12 \\
\hline $\mathbf{A}$ & Std -2 & Std -2 & 1 dpi 0 & 2dpi 0 & 3dpi 0 & 4dpi 0 & 5dpi 0 & 6dpi 0 & 7dpi 0 & 8dpi 0 & 9dpi 0 & 10dpi 0 \\
\hline B & Std -3 & Std -3 & $1 \mathrm{dpi}-1$ & 2dpi -1 & 3dpi -1 & 4dpi -1 & 5dpi -1 & 6dpi -1 & 7dpi -1 & 8dpi -1 & $9 \mathrm{dpi}-1$ & $10 \mathrm{dpi}-1$ \\
\hline C & Std -4 & Std -4 & $1 \mathrm{dpi}-2$ & 2dpi -2 & 3dpi -2 & $4 d p i-2$ & $5 \mathrm{dpi}-2$ & 6dpi -2 & 7dpi -2 & 8dpi -2 & $9 d p i-2$ & 10dpi -2 \\
\hline D & Std -5 & Std -5 & $1 \mathrm{dpi}-3$ & $2 d p i-3$ & 3dpi -3 & $4 d p i-3$ & $5 d p i-3$ & 6dpi -3 & 7dpi -3 & 8dpi -3 & 9dpi -3 & $10 \mathrm{dpi}-3$ \\
\hline E & & & $1 \mathrm{dpi}-4$ & 2 dpi -4 & 3dpi -4 & $4 \mathrm{dpi}-4$ & $5 \mathrm{dpi}-4$ & 6dpi -4 & 7dpi -4 & 8dpi -4 & $9 d p i-4$ & 10dpi -4 \\
\hline$F$ & & & $1 \mathrm{dpi}-5$ & 2dpi -5 & 3dpi -5 & 4dpi -5 & $5 d p i-5$ & $6 \mathrm{dpi}-5$ & 7dpi -5 & 8dpi -5 & 9dpi -5 & $10 \mathrm{dpi}-5$ \\
\hline $\mathbf{G}$ & CC & & $1 \mathrm{dpi}-6$ & 2dpi -6 & 3dpi -6 & 4dpi -6 & $5 \mathrm{dpi}-6$ & 6dpi -6 & 7dpi -6 & 8dpi -6 & 9dpi -6 & $10 \mathrm{dpi}-6$ \\
\hline $\mathrm{H}$ & $\mathrm{CC}$ & & & & & & & & & & & \\
\hline
\end{tabular}

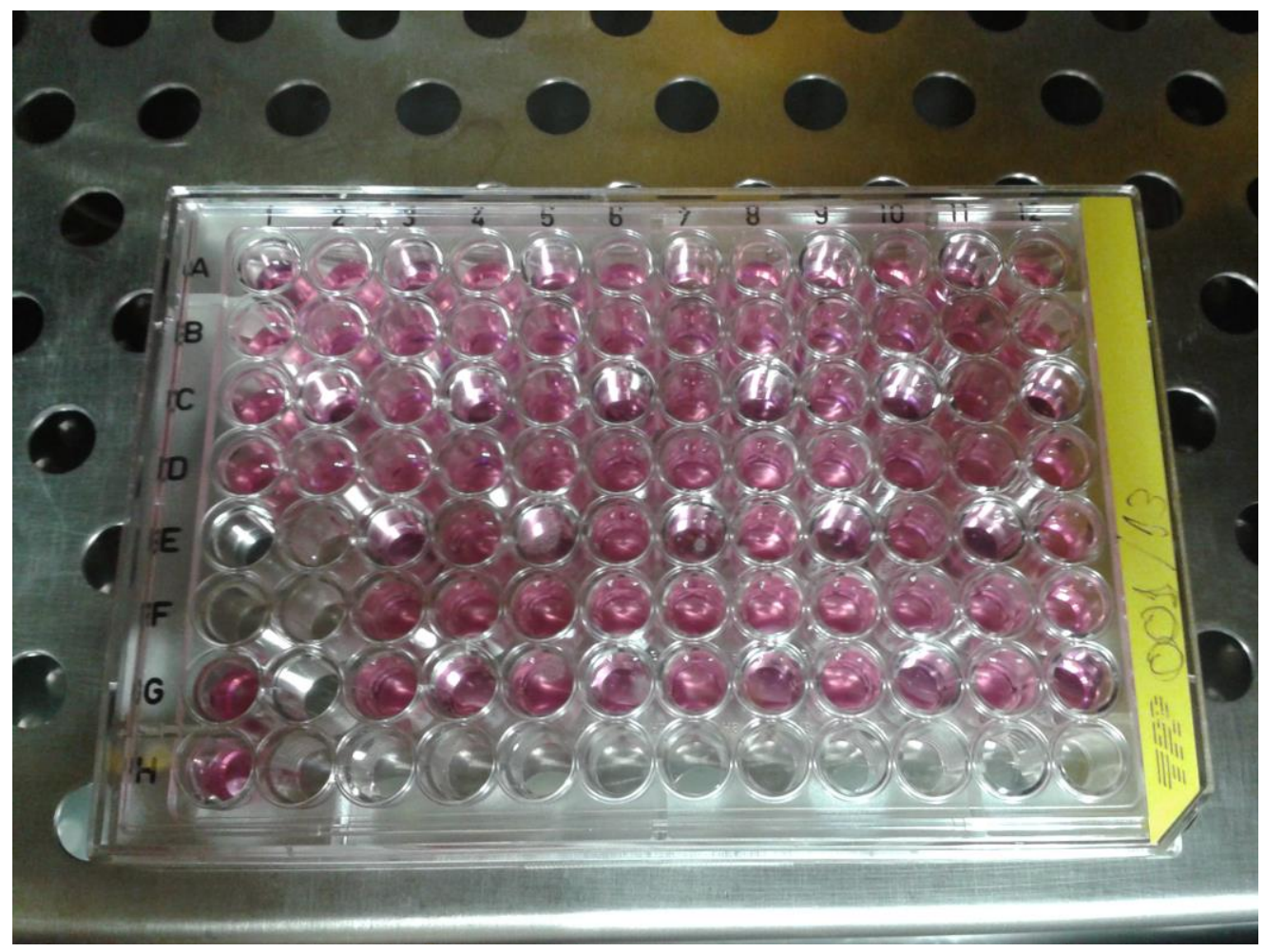

Figure 3.4: Example of one microplate filled with samples. 


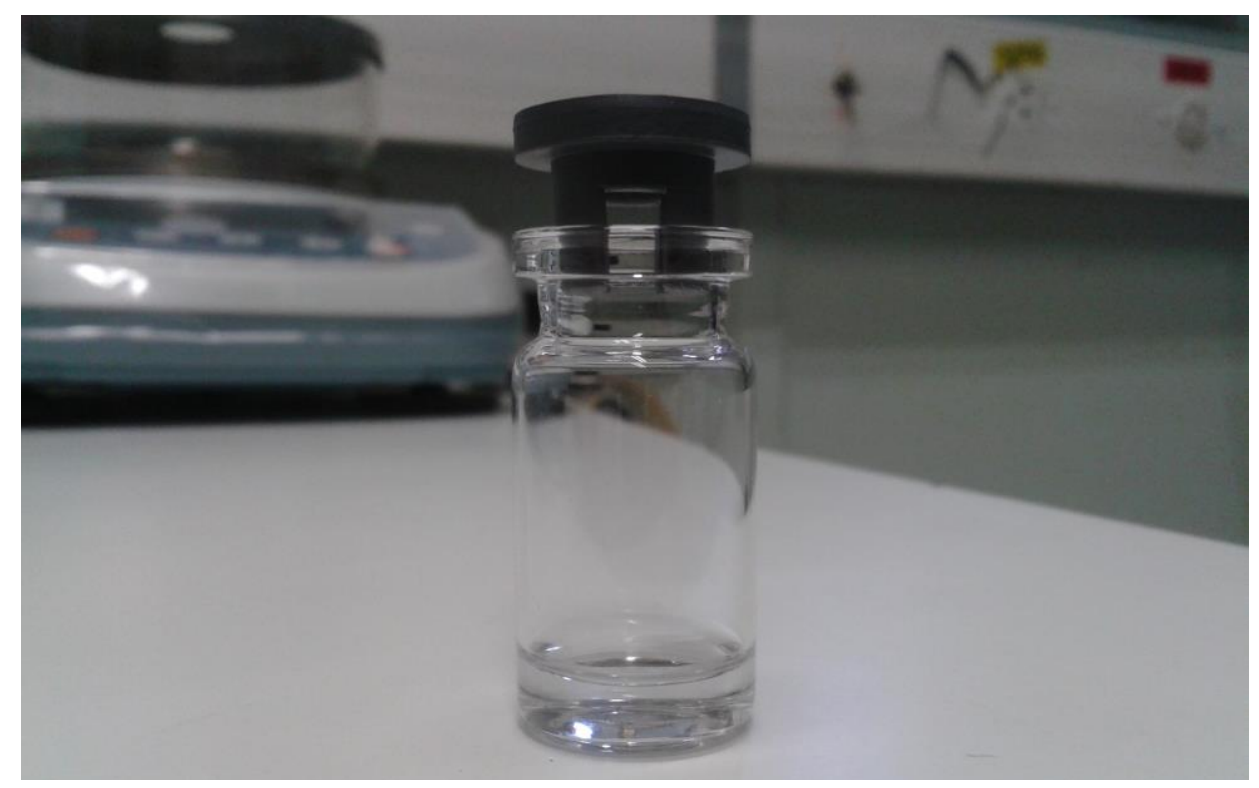

Figure 3.5: $7.5 \mathrm{~mL}$ glass vial filled with $1 \mathrm{~mL}$ and partially closed with a rubber stopper.

Table 3.3: NT ( $\mathrm{NaCl}$ - Tris) Buffer for buffer exchange of IVS.

\begin{tabular}{|c|c|}
\hline Reagent (molarity) & Mass used \\
\hline $\mathrm{NaCl}(0.13 \mathrm{~mol} / \mathrm{L})$ & $7.600 \mathrm{~g}$ \\
\hline Tris- $\mathrm{HCl}(0.05 \mathrm{~mol} / \mathrm{L})$ & $6.057 \mathrm{~g}$ \\
\hline $\mathrm{pH}$ adjusted to 7.6 \\
\hline Purified water added to complete $1 \mathrm{~L}$ \\
\hline
\end{tabular}




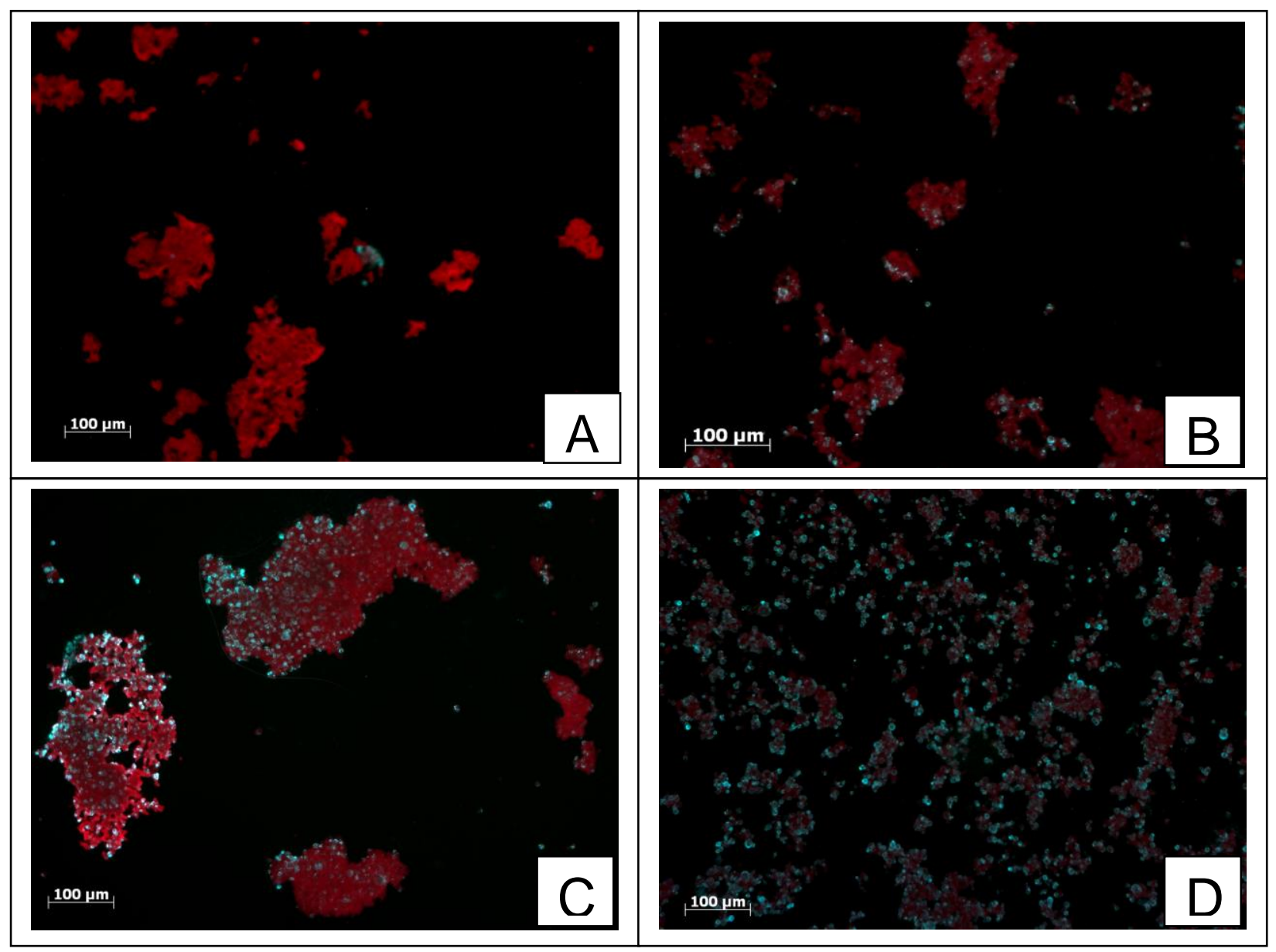

Figure 4.2 Examples of classes in a direct immunofluorescence assay. The cells are stained in red and the virus in green. The magnificence of the images is 50 times although during the test the evaluation is done using 100 times. A - Class 1: from rare focus to $25 \%$ of fluorescent focuses (Pos. Control at $1 \mathrm{dpi}$ ); B - Class 2: from $25 \%$ to $50 \%$ of fluorescent focuses (MOI 0.01 at 2 dpi); C - Class 3: from $50 \%$ to $75 \%$ of fluorescent focuses (Pos. Control at 2 dpi); D - Class 4: more than $75 \%$ fluorescent focuses (MOI 0.03 at $4 \mathrm{dpi}$ ). 


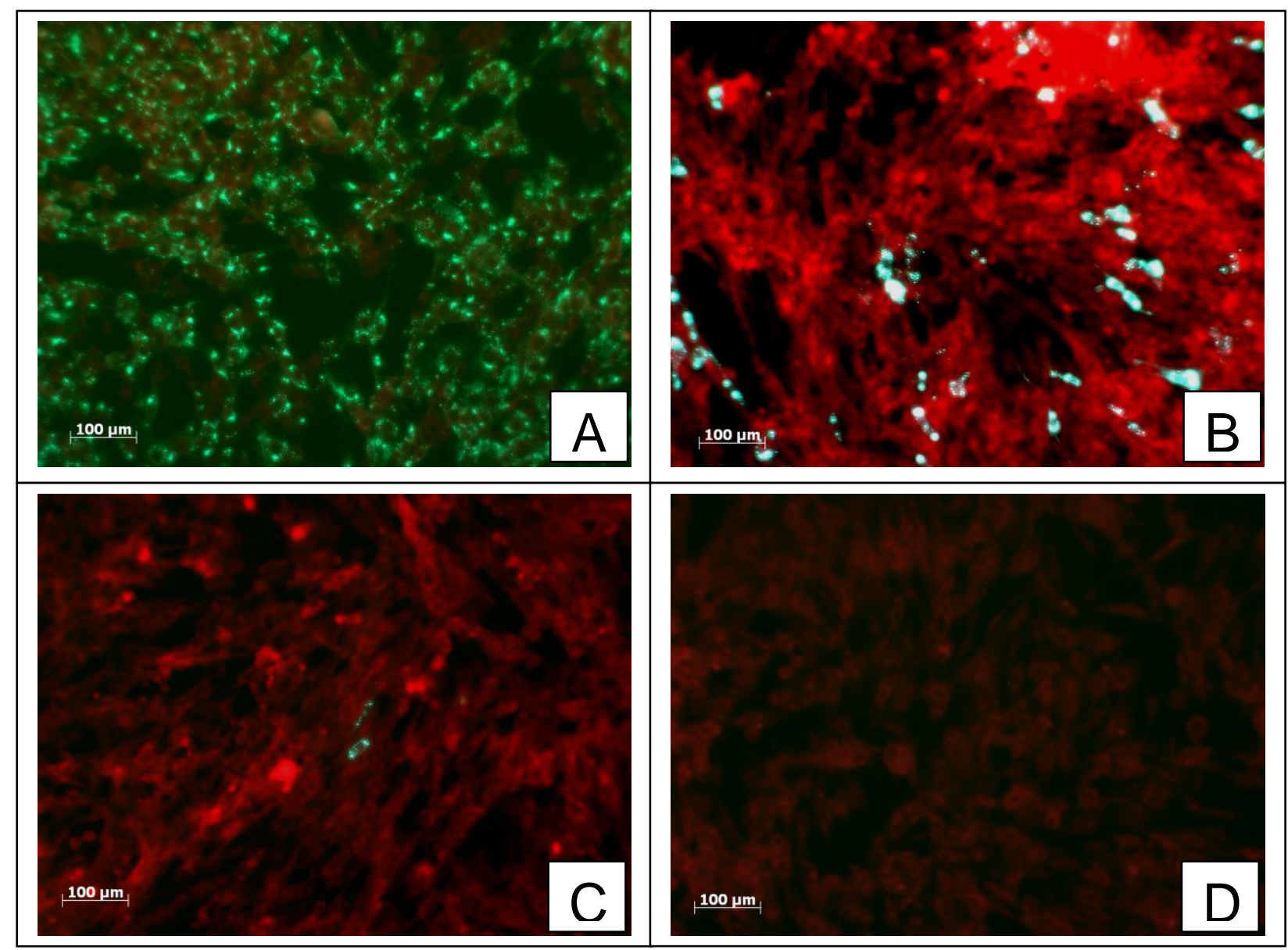

Figure 4.4 Examples of positive and negative fields in the rabies virus titration. The cells are stained in red and the virus in green. The magnificence of the images is 100 times. A - Positive field with a great amount of virus (MOI 0.03 at 3 dpi with $10^{-1}$ dilution); $\mathrm{B}-$ Positive field with more diluted virus (MOI 0.03 at $3 \mathrm{dpi}$ with $10^{-2}$ dilution); $\mathrm{C}-2$ fluorescent focus yet positive field (MOI 0.03 at $3 \mathrm{dpi}$ with $10^{-5}$ dilution); $\mathrm{D}-$ Negative field (MOI 0.03 at 5 dpi with $10^{-5}$ dilution). 


\section{References}

BATISTA, A. M.; CRUZ, P. S.; ALMEIDA, E.; COSTA, A. E. B.; SCHEFFER, K. C.; CHAVES, L. B.; SILVA, A. C. R.; CAPORALE, G. M. M. Infection of BHK-21 cells cultivated in stationary monolayers by PV and CVS strains (In Portuguese). Boletim Epidemiológico Paulista (BEPA), v. 6, p. 1-7, 2009.

BATISTA, H. B. C. R.; FRANCO, A. C.; ROEHE, P. M. Raiva: uma breve revisão (In Portuguese). Acta Scientiae Veterinariae, v. 35, p. 125-144, 2007.

BRASIL - Ministério da Agricultura, Pecuária e Abastecimento (MAPA). Portaria № 228/1988 (In Portuguese). Available in:

http://sistemasweb.agricultura.gov.br/sislegis/action/detalhaAto.do?method=visuali zarAtoPortalMapa\&chave $=58090151$

BRIGGS, D. J.; DRESSEN, D. W.; WUNNER, W. H. Vaccines. In: Rabies First Edition (A. C. Jackson, W. H. Wunner, eds.). New York: Academic Press, p. 379, 2002.

BOURHY, H.; SUREAU, P.; TORDO, N. From rabies to rabies-related viruses. Veterinary Microbiology, v. 23, p. 115-128, 1990.

BUNN, T. O. Canine and feline rabies vaccines, past and present. In: The Natural History of Rabies (G.M. Baer, ed.). Boca Raton: CRC Press, p. 415-425, 1991.

CARICATI, A. T. P. Estratégias do processo para a conservação da potência da vacina rábica de uso veterinário por liofilização (In Portuguese). Master's Dissertation. Programa de Pós-Graduação em Tecnologia BioquímicoFarmacêutica, Universidade de São Paulo, São Paulo, 2012.

CHAPMAN, W. G.; RAMSHAW, I. A.; CRICK, J. Inactivated rabies vaccine produced from the Flury LEP strain of virus grown in BHK-21 suspension cells. Applied Microbiology, v. 26, p. 858-862, 1973.

CRUZ, H. J.; FREITAS, C. M; ALVES, P. M; MOREIRA, J. L; CARRONDO, M.J.T. Effects of ammonia and lactate on growth, metabolism, and productivity of BHK cells. Enzyme and Microbial Technology, v. 27, p. 43-52, 2000.

DAVIES, M. C.; ENGLERT, M. E.; SHARPLESS, G. R.; CABASSO, V. J. The electron microscopy of rabies virus in cultures of chicken embryo tissues. Virology, v. 21, p. 642-651, 1963.

FENJE, P. A rabies vaccine from hamster kidney tissue cultures: preparation and evaluation in animals. Canadian Journal of Microbiology, v. 6, p. 605-609, 1960. 
FUCHES, R. M. M. Validação de bioensaios para o estudo da imunogenicidade da vacina contra raiva (In Portuguese). Doctoral's Thesis. Programa de Pósgraduação Interunidades em Biotecnologia, USP/Instituto Butantan/IPT, São Paulo, 2010.

FUENZALIDA, E.; PALACIOS, R. Un metodo mejorado para la preparacion de la vacuna antirrábica (In Spanish). Boletín del Instituto de Bacteriología de Chile, v. 8, p. 3-11, 1955.

FUREY, J. Continuous Cell Culture Using the ATF System. Genetic Engineering News, v. 20, p. 52-53, 2000.

GUIDOLIN, R.; BALTAZAR, M. C.; ZELANTE, F. Produção de vacina antirrábica veterinária em suspensão de células BHK (In Portuguese). Revista de Microbiologia, v. 14, p. 27-35, 1983.

GUPTA, C. K.; LESZCZYNSKI, J.; GUPTA, R. K.; SIBER G. R. Stabilization of respiratory syncytial virus (RSV) against thermal inactivation and freeze-thaw cycles for development and control of RSV vaccines and immune globulin. Vaccine, v.14, p. 1417-1420, 1996.

HIROSE, J. A. M.; VILLEGAS, A. E. M. Estructura antigenica y mecanismos de infeccion del virus de la rabia (In Spanish). Ciencia Veterinaria, v. 7, p. 67-102, 1996.

HUBÁLEK, Z. Protectants used in the cryopreservation of microorganisms. Cryobiology, v. 46, p. 205-229, 2003.

JENNINGS, T. A. Introduction. In: Lyophilization: Introduction and basic principles (Informa Healthcare USA Inc., ed.). New York: CRC Press, p. 1-10, 2008.

JOHNSON, N.; CUNNINGHAM, A. F.; FOOK, A. R. The immune response to rabies virus infection and vaccination. Vaccine, v. 28, p. 3896-3901, 2010.

KALLEL, H.; JOUINI, A.; MAJOUL, S.; ROUROU, S. Evaluation of various serum and animal protein free media for the production of a veterinary rabies vaccine in BHK-21 cells. Journal of Biotechnology, v. 95, p. 195-204, 2002.

LANG, R.; WINTER, G. Rational design of a stable, freeze-dried virus-like particlebased vaccine formulation. Drug Development and Industrial Pharmacy, v. 35, p. 83-97, 2009.

LAW, T. J.; HULL, R.N. Stabilizing effect of sucrose upon respiratory syncytial virus infectivity. Experimental Biological Medicine, v. 128, p. 515-518, 1968. 
MAZARAKIS, N. D.; AZZOUZ, M.; ROHELL, J. B. Rabies virus glycoprotein pseudotyping of lentiviral vectors enables retrograde axonal transport and access to the nervous system after peripheral delivery. Human Molecular Genetics, v. 10, p. 2109-2121, 2001.

MOURA, W. C., GALLINA, N. M. F.; FUCHES, R. M. M.; ROMIJN, P. C.; LEITE, J. P. G. Validation of a virus neutralization potency test in BHK-21 cells for rabies immunoglobulins in a two-center study. Journal of Virological Methods, v. 154, p. 7-13, 2008.

MURPHY, F. A.; FAUQUET, C. M.; BISHOP, D. H. L.; GHABRIAL, S. A.; JARVIS, A. W.; MARTELLI, G. P.; MAYO, M. A.; SUMMERS, M. D. Virus taxonomy: classification and nomenclature of viruses. Sixth report of the International Committee on Taxonomy of Viruses (F. A. Murphy, ed.). New York: SpringerVerlag, 1995.

NADIN-DAVIS, S. A. Rabies: Virus and Disease. Published online in 2010. Available in: http://www.els.net/WileyCDA/ElsArticle/refld-a0002244.html.

PECK, F. B.; POWELL, H. M.; CULBERTSON, C. G. A new antirabies vaccine for human use, clinical and laboratory results using rabies vaccine made from embryonated duck eggs. Journal of Laboratory and Clinical Medicine, v. 45, p. 679-683, 1955.

PHILLIPS, H. J. Dye exclusion tests for cell viability. In: Tissue culture: Methods and Applications (P. F. Kruse Jr. and M. K. Patterson ed.). New York: Academic Press, p. 406-408, 1973.

PERRIN, P.; MADHUSUDANA, S.; GONTIER-JALLET, C.; PETRES, S.; TORDO, N.; MERTEN, O.-W. An experimental rabies vaccine produced with a new BHK-21 suspension cell culture process: use of serum-free medium and perfusion-reactor system. Vaccine, v. 13, p. 1244-1250, 1995.

PRECAUSTA, P.; SOULEBOT, J.-P. Vaccines for domestic animals. In: The Natural History of Rabies (G.M. Baer, ed.), p. 445-459. Boca Raton: CRC Press, 1991.

RACANIELLO, V. Multiplicity of infection, 2011. Available in: http://www.virology.ws/2011/01/13/multiplicity-of-infection/

RECULARD, P. Cell-culture vaccines for veterinary use. In: Laboratory techniques in rabies (F.-X. Meslin, M.M., Kaplan, H. Koprowski, eds.). Geneva: WHO Library, 1996.

ROUMIANTZEFF, M.; AJJAN, N.; MONTAGNON, B; VINCENT-FALQUET, J. C. Rabies vaccines produced in cell culture. Annales de l'Institut Pasteur/Virologie, v. 136, p. 413-424, 1985. 
SARKAR, J.; SREENIVASA, B. P.; SINGH, R.P.; DHAR, P.; BANDYOPADHYAY, S. K. Comparative efficacy of various chemical stabilizers on the thermostability of a live-attenuated peste de petits ruminants (PPR) vaccine. Vaccine, v. 21, p. 47284735, 2003.

SUREAU, P. Contribution to rabies prevention. Vaccine, v. 10, p. 896-899, 1992.

SEHGAL, O. P.; DAS, P. D. Effect of freezing on conformation and stability of the virions of southern bean mosaic virus. Virology, v. 64, p. 180-186, 1975.

TONSO, A. Monitoramento e operação de cultivos de células animais em sistemas de perfusão (In Portuguese). Doctoral's Thesis. Universidade de São Paulo, São Paulo, 2000.

TRABELSI, K.; ROUROU, S.; LOUKIL, H.; MAJOUL, S.; KALLEL, H. Comparison of various culture modes for the production of rabies virus by Vero cells grown on microcarriers in a 2-L bioreactor. Enzyme and Microbial Technology, v. 36, p. 514-519, 2005.

TRABELSI, K.; ROUROU, S.; LOUKIL, H.; MAJOUL, S.; KALLEL, H. Optimization of virus yield as a strategy to improve rabies vaccine production by Vero cells in a bioreactor. Journal of Biotechnology, v. 121, 261-271, 2006.

WANG, W. Lyophilization and development of solid protein pharmaceuticals. International Journal of Pharmaceuticals, v. 203, p. 1-60, 2000.

WEBOMETRICS. Ranking Web of Universities. Available in: http://www.webometrics.info/en

WHO - World Health Organization. Rabies Vaccines: WHO position paper. Weekly epidemiological record No. 32, 2010. Available in:

http://www.who.int/wer/2010/wer8532.pdf

WHO - World Health Organization. Rabies: countries or areas at risk, 2012. Available in: http://www.who.int/rabies/rabies_maps/en/

WHO - World Health Organization. Vaccine definition. Available in: http://who.int/topics/vaccines/en/

WHO - World Health Organization. WHO Expert consultation on rabies (first report). WHO Technical Report Series No. 931, 2005. Available in:

http://whqlibdoc.who.int/trs/WHO_TRS_931_eng.pdf

WHO - World Health Organization. WHO Expert consultation on rabies (second report). WHO Technical Report Series No. 982, 2013. Available in: http://apps.who.int/iris/bitstream/10665/85346/1/9789241209823_eng.pdf 
WUNNER, W. H. Rabies Virus. In: Rabies Second Edition (A. C. Jackson, W. H. Wunner, eds.). New York: Academic Press, p. 23-69, 2007.

WUNNER, W. H. The chemical composition and molecular structure of rabies viruses. In: The Natural History of Rabies (G. M. Baer, ed.). Boca Raton: CRC Press, p. 31-67, 1991.

ZENG A. P.; HU, W. S.; DECKWER, W.D. Variation of stoichiometric ratios and their correlation for monitoring and control of animal cell cultures. Biotechnology Progress, v. 14, p. 434-441, 1998. 